\title{
Gene Therapy for Liver Cancers: Current Status from Basic to Clinics
}

\author{
Kenya Kamimura *(D), Takeshi Yokoo ${ }^{D}$, Hiroyuki Abe and Shuji Terai \\ Division of Gastroenterology and Hepatology, Graduate School of Medical and Dental Sciences, Niigata \\ University, 1-757, Aasahimachi-Dori, Chuo-Ku, Niigata 9518510, Japan; t-yokoo@med.niigata-u.ac.jp (T.Y.); \\ hiroyukiabe@med.niigata-u.ac.jp (H.A.); terais@med.niigata-u.ac.jp (S.T.) \\ * Correspondence: kenya-k@med.niigata-u.ac.jp; Tel.: +81-25-227-2207; Fax: +81-25-227-0776
}

Received: 30 October 2019; Accepted: 21 November 2019; Published: 25 November 2019

\begin{abstract}
The liver is a key organ for metabolism, protein synthesis, detoxification, and endocrine function, and among liver diseases, including hepatitis, cirrhosis, malignant tumors, and congenital disease, liver cancer is one of the leading causes of cancer-related deaths worldwide. Conventional therapeutic options such as embolization and chemotherapy are not effective against advanced-stage liver cancer; therefore, continuous efforts focus on the development of novel therapeutic options, including molecular targeted agents and gene therapy. In this review, we will summarize the progress toward the development of gene therapies for liver cancer, with an emphasis on recent clinical trials and preclinical studies.
\end{abstract}

Keywords: gene therapy; liver; cancer; hepatocellular carcinoma; metastatic liver tumors

\section{Introduction}

The liver is the largest organ in the body and has vital functions in protein synthesis, metabolism, and detoxification that play key roles in maintaining homeostasis. There are a number of serious liver diseases including hepatitis, fibrosis, genetic diseases, metabolic diseases, and liver cancer, which is one of the leading causes of cancer-related deaths worldwide [1-3].

\subsection{Liver Cancers}

The primary liver cancer is mainly hepatocellular carcinoma (HCC) [2], and its etiology includes viral hepatitis, alcohol addiction, and metabolic diseases [4]. Therefore, HCC can occur in diseased liver and involves various molecular pathways [5]. Other primary liver cancers include cholangiocarcinoma, fibrolamellar carcinoma, hepatoblastoma, angiosarcoma, and other mesenchymal cancers of the liver $[2,6]$. Secondary liver cancers include metastatic tumors from the breast, lung, pancreas, and colorectal cancers [6].

\subsubsection{Hepatocellular Carcinoma}

In HCC, which consists of more than $90 \%$ of primary liver cancers [2,3], the consideration of the remaining hepatic function is essential in the determination of the therapeutic options [7-9]. In other words, HCC patients with poor hepatic reserve function have imitated therapeutic options [3]. HCC is a highly heterogeneous cancer, which has recently been demonstrated by high-throughput sequencing and gene expression profiling, at both the molecular and histological level [10]. Although conventional therapeutic options of surgery, ablation, chemoembolization, systemic chemotherapy, and molecularly targeted agents are partly effective for HCC, they are not sufficient for advanced-stage HCC in terms of its efficacy. The effectiveness of chemotherapy in HCC is restricted by chemo-resistance and systemic 
side effects. To improve the efficacy and safety of chemotherapeutics in HCC management, targeted carriers such as nanoparticles have been tested for efficacy in basic research, but are not yet sufficient to take to clinics [11]. Recent development in the field of molecular targeted agent (MTA) has shed light on chemotherapy for HCC [12] with the consideration of the molecular expression differences in the tumor. However, these MTAs also have limitations owing to the heterogeneity of HCC, and signaling pathway-specific inhibitors, such as those inhibiting fibroblast growth factor (FGF) 19-FGFR4 signaling pathways, are used in clinical trials [13]. Immune checkpoint inhibitors have also been tested [14], but have shown low efficacy in HCC as a current strategy, and further modification of the immune environment is essential [15-17]. Overall, HCC is characterized by heterogeneity [18-21], high risk of recurrence, and drug resistance. Therefore, with the large number of cases worldwide, new approaches are required for early diagnosis, real-time monitoring, molecular-based diagnosis, and definition of therapeutic targets and effective treatment.

\subsubsection{Metastatic Liver Cancer}

Metastatic liver tumors can be diagnosed more often than primary liver cancers. Therefore, the selective therapeutic options for the tumor in the liver have been considered in combination with the therapy for the primary lesions including the breast, lung, pancreas, and colorectal cancers [6]. In addition, currently, the genomic information in the tumor tissues can be easily obtained using next generation sequencing.

On the basis of these significant developments and advances in the techniques of molecular biology [5,22], innovative basic research and clinical trials, focusing on the development of gene therapy for liver cancers, are increasing [23,24]; together, these have the potential to offer long therapeutic benefit and overcome the issue of heterogeneity.

\subsection{Gene Therapy}

In a disease where novel therapeutic innovations are sorely needed, combining novel therapies of gene therapy approaches with the currently available cytotoxic chemotherapeutic drugs and radiation therapy [25-27] also provides hope for better outcomes in patients with advanced-stage liver cancers, including primary and secondary liver cancers.

In this review, we will summarize the progress toward the development of gene therapies for liver cancers including both primary and secondary tumors, with an emphasis on recent clinical trials and preclinical studies including the gene delivery procedures. In addition, clinical trials focusing on gene expression-based diagnosis and the decision of therapeutic options to apply personalized medicine are summarized based on the information available [28]. Therefore, this review summarizes the current landscape of ongoing and completed clinical studies on liver cancers, provides a review of the basic research, and will help both the physicians and researchers to conduct clinical trials and develop novel gene therapy.

\section{Gene Therapy for the Liver Cancers}

\subsection{Liver-Directed Gene Therapy}

Because of its sophisticated and important function in maintaining homeostasis, various diseases originate in the liver. These diseases include genetic disorders such as hemochromatosis, hemophilia A and B, alpha 1 antitrypsin deficiency, Wilson's disease, Crigler-Najjar syndrome type I, ornithin transcarbamylase deficiency, type IIa familial hypercholesterolemia, and afibrogenemia. Therefore, basic studies focusing on the genetics-based diagnosis of these diseases; molecular biology studies on the mechanisms of these diseases; and the development of genetics-based therapeutic options, "gene therapy", for these liver diseases have been extensively studied. Gene therapy has evolved as a potent means of treatment for pathogenic gene defects to achieve normal status. The strategies used to treat 
disease by gene therapy include gene replacement; gene repair; gene augmentation; gene silencing; vaccination; and, currently, gene editing technology [29-32].

In addition, the liver has unique anatomical characteristics with three vascular systems of the portal vein, hepatic artery, and hepatic veins and bile ducts, and consists of various types of cells including hepatocytes, endothelial cells in the sinusoids, Kupffer cells, dendritic cells, stellate cells (Ito cells), macrophages, natural killer cells (pit cells), and cholangiocytes. The perisinusoidal space between the endothelial cells in the sinusoid and the hepatocytes is called the "Space of Disse", and the endothelial cells have fenestrae of about $100 \mathrm{~nm}$ in diameter on their surface, which brings blood substances or particles into the space and in contact with the hepatocytes [1]. Therefore, the primary barrier for nucleic acid delivery to the hepatocytes is the plasma membrane and the endothelium, in cases where the molecules are larger than $100 \mathrm{~nm}$ and the gene delivery methods used to reach the liver through these anatomical routes and cells have been studied previously $[25,27]$. The challenges for successful gene therapy for liver cancer are to deliver gene/nucleic acids and cells to the cancer cells without causing irreversible tissue damages. The current gene delivery methods used in liver diseases are summarized in Table 1.

Table 1. Gene delivery methods used in clinical and preclinical stages.

\begin{tabular}{|c|c|c|c|c|}
\hline $\begin{array}{l}\text { Gene Transfer } \\
\text { Methods }\end{array}$ & $\begin{array}{l}\text { Genetic Materials } \\
\text { (Cloning Capacity)/ } \\
\text { Functional } \\
\text { Component }\end{array}$ & \multicolumn{2}{|c|}{ Advantages } & Disadvantages \\
\hline \multicolumn{5}{|l|}{ Viral Vectors } \\
\hline \multicolumn{5}{|l|}{ Retroviral Vectors } \\
\hline Oncoretrovirus & $\begin{array}{l}\text { Single stranded RNA } \\
\qquad(8 \mathrm{~kb})\end{array}$ & High transduction efficiency & $\begin{array}{l}\text { Infect to dividing } \\
\text { cells }\end{array}$ & $\begin{array}{l}\text { Random integration Low } \\
\text { efficiency of purification }\end{array}$ \\
\hline Lentivirus & $\begin{array}{l}\text { Single stranded RNA } \\
\qquad(8 \mathrm{~kb})\end{array}$ & $\begin{array}{l}\text { High transduction efficiency } \\
\text { Sustained gene expression } \\
\text { Low immune response }\end{array}$ & $\begin{array}{l}\text { Infect to dividing } \\
\text { and non-dividing } \\
\text { cells }\end{array}$ & $\begin{array}{l}\text { Random integration Low } \\
\text { efficiency of purification }\end{array}$ \\
\hline Foamy virus & $\begin{array}{l}\text { Single stranded RNA } \\
\qquad(9.2 \mathrm{~kb})\end{array}$ & $\begin{array}{l}\text { High transduction efficiency } \\
\text { Sustained gene expression } \\
\text { No expression of viral } \\
\text { proteins Low immune } \\
\text { response }\end{array}$ & $\begin{array}{l}\text { Infect to dividing } \\
\text { cells Form a stable } \\
\text { transduction } \\
\text { intermediate in } \\
\text { non-dividing cells }\end{array}$ & $\begin{array}{l}\text { Random integration Low } \\
\text { efficiency of purification }\end{array}$ \\
\hline \multicolumn{5}{|l|}{$\begin{array}{l}\text { Adenoviral } \\
\text { Vectors }\end{array}$} \\
\hline $\begin{array}{l}\text { First generation } \\
\text { adenovirus (FGAd) }\end{array}$ & $\begin{array}{l}\text { Double stranded DNA } \\
\qquad(8-10 \mathrm{~kb})\end{array}$ & High transduction efficiency & $\begin{array}{l}\text { Infect to dividing } \\
\text { and non-dividing } \\
\text { cells }\end{array}$ & $\begin{array}{l}\text { Transient expression } \\
\text { Host innate immune } \\
\text { response Complicated } \\
\text { vector production }\end{array}$ \\
\hline $\begin{array}{l}\text { Helper-dependent } \\
\text { adenovirus } \\
\text { (HDAd) }\end{array}$ & $\begin{array}{l}\text { Double stranded DNA } \\
\qquad(\sim 37 \mathrm{~kb})\end{array}$ & $\begin{array}{c}\text { Large insert size Essentially } \\
\text { no integration }\end{array}$ & $\begin{array}{l}\text { Infect to dividing } \\
\text { and non-dividing } \\
\text { cells }\end{array}$ & $\begin{array}{l}\text { Transient expression } \\
\text { Host innate immune } \\
\text { response Complicated } \\
\text { vector production }\end{array}$ \\
\hline $\begin{array}{l}\text { Adeno-associated } \\
\text { virus }\end{array}$ & $\begin{array}{l}\text { Single stranded DNA } \\
\qquad(4-5 \mathrm{~kb})\end{array}$ & $\begin{array}{l}\text { Non pathogenic Sustained } \\
\text { gene expression Mainly no } \\
\text { integration Low immune } \\
\text { response }\end{array}$ & $\begin{array}{l}\text { Infect to dividing } \\
\text { and non-dividing } \\
\text { cells }\end{array}$ & $\begin{array}{l}\text { Integration may occur } \\
\text { Small capacity of } \\
\text { transgene Transient } \\
\text { expression Complicated } \\
\text { vector production }\end{array}$ \\
\hline $\begin{array}{l}\text { Herpes simplex } \\
\text { virus }\end{array}$ & $\begin{array}{l}\text { Double stranded DNA } \\
\qquad(\sim 30 \mathrm{~kb})\end{array}$ & $\begin{array}{l}\text { Large insert size No } \\
\text { integration Sustained gene } \\
\text { expression }\end{array}$ & $\begin{array}{l}\text { Infectivity to } \\
\text { nervous system }\end{array}$ & $\begin{array}{l}\text { Transient expression } \\
\text { Low transduction } \\
\text { efficiency }\end{array}$ \\
\hline \multicolumn{5}{|l|}{$\begin{array}{l}\text { Non-viral Vectors } \\
\text { (Chemicals) }\end{array}$} \\
\hline Cationic lipids & $\begin{array}{l}\text { Cationic charge, } \\
\text { hydrophobic domain }\end{array}$ & \multicolumn{2}{|c|}{ High efficiency in vitro, ease to prepare } & $\begin{array}{l}\text { Low efficiency in vivo, } \\
\text { acute immune response }\end{array}$ \\
\hline Cationic polymers & $\begin{array}{l}\text { Cationic charge, } \\
\text { polymer }\end{array}$ & \multicolumn{2}{|c|}{ Highly effective in vitro, ease to prepare } & $\begin{array}{l}\text { Toxic to cells, acute } \\
\text { immune response }\end{array}$ \\
\hline
\end{tabular}


Table 1. Cont.

\begin{tabular}{|c|c|c|c|}
\hline $\begin{array}{l}\text { Gene Transfer } \\
\text { Methods }\end{array}$ & $\begin{array}{c}\text { Genetic Materials } \\
\text { (Cloning Capacity)/ } \\
\text { Functional } \\
\text { Component }\end{array}$ & Advantages & Disadvantages \\
\hline Proteins & $\begin{array}{l}\text { Natural or chemically } \\
\text { modified proteins in } \\
\text { cationic nature }\end{array}$ & $\begin{array}{l}\text { Highly effective in vitro, less toxic, can be target } \\
\text { specific }\end{array}$ & Low activity in vivo \\
\hline Peptides & $\begin{array}{l}\text { Lysine or arginine } \\
\text { residues in peptides }\end{array}$ & $\begin{array}{l}\text { Highly effective in vitro, less toxic, can be target } \\
\text { specific }\end{array}$ & Low activity in vivo \\
\hline \multicolumn{4}{|l|}{$\begin{array}{c}\text { Non-viral Vectors } \\
\text { (Physical } \\
\text { Methods) }\end{array}$} \\
\hline Needle injection & Mechanic force & Simple & $\begin{array}{l}\text { Low efficiency, } \\
\text { expression limited to } \\
\text { needle track }\end{array}$ \\
\hline Gene gun & Pressure & Ease, Good efficiency & $\begin{array}{l}\text { Limited to target area, } \\
\text { need surgical procedure } \\
\text { for internal organ }\end{array}$ \\
\hline Electroporation & Electric pulse & High efficiency & $\begin{array}{c}\text { Tissue damage, limited } \\
\text { target area, need surgical } \\
\text { procedure for internal } \\
\text { organ }\end{array}$ \\
\hline Sonoporation & Ultrasound & Simple, can be site-specific & $\begin{array}{l}\text { Low efficiency, tissue } \\
\text { damage }\end{array}$ \\
\hline Magnetofection & Magnetic field & Site specific & $\begin{array}{l}\text { Low efficiency, limited } \\
\text { target area, need surgical } \\
\text { procedure for internal } \\
\text { organ }\end{array}$ \\
\hline $\begin{array}{l}\text { Hydrodynamic } \\
\text { delivery }\end{array}$ & $\begin{array}{l}\text { Hydrodynamic } \\
\text { pressure }\end{array}$ & Simple, high efficiency in vivo, site specific & $\begin{array}{c}\text { Need catheter insertion } \\
\text { technique in large } \\
\text { animals }\end{array}$ \\
\hline Immunotherapy & CAR-T, T cells & Antigen-specific & $\begin{array}{l}\text { Require ex vivo cell } \\
\text { culture Poorly effective } \\
\text { for solid tumors }\end{array}$ \\
\hline Gene Vaccination & $\begin{array}{l}\text { Antigen-pulsed } \\
\text { dendritic cells }\end{array}$ & Ease to prepare less toxic, ease to administer & Low efficacy \\
\hline
\end{tabular}

\subsection{Target Genes for HCC Gene Therapy}

With increased knowledge of the molecular-based analyses for HCC [33,34], various basic studies are ongoing to develop novel gene therapy for HCC. These studies include epigenetic changes [35], integration in the genome [36], protein expression [37], endothelial growth factor receptor (EGFR) signaling pathway [38], EGFR/ Hypoxia Inducible Factor- $1 \alpha$ /vascular EGF (VEGF) pathways under hypoxic conditions [39-41], target gene discovery through copy number alteration [42], and genomic profiling of rare liver cancer [43]. Among them, copy number alterations are one of the most common alterations of cancer cells that result in gain or loss of function of oncogene and tumor suppressor genes; therefore, these can be a target of gene therapy as well as genetic markers [18].

Progress has been made in overcoming the issue of the heterogeneity of liver cancer by utilizing genomic information, two-dimentional culture systems, and patient-derived primary cancer cells [44,45]. The exome and whole cancer genome analyses in human HCC frequently identify mutated somatic genes, including p53, CTNNB1, AXIN1, ARID1A, ARID2, MLL, MLL2, MLL3, MLL4, IRF2, ATM, $C D K N 2 A$, and FGF19 [42]. Potential therapeutic targets for which inhibitors currently exist include the WNT signaling pathway, MDM4, MET, VEGFA, MCL1, IDH1, TERT, and various immune checkpoint proteins [46]. On the basis of these findings, the modification of genes related to tumor suppressors, oncogenes, those encoding the proteins expressed on the tumor cell surface, and the T-cell receptor to target the tumor, as well as genetic immunotherapy, have been tested in both basic and clinical research $[22-24,46]$. 


\subsubsection{Tumor Suppressor Genes}

The abnormalities in tumor suppressor gene signaling pathways, including p53 and its negative regulator Mouse double minute 2 homolog (MDM2, are often found in HCCs [20,33,42]. Therefore, the restoration of tumor suppressor genes has been tested for its clinical applicability. Among them, p53 has been tested in several trials for HCC (NCT00003147, NCT02561546, NCT02509169, NCT02418988, and NCT02432963), as well as p53 gene vaccination for other liver tumors, including metastatic tumors from other organs (NCT02432963). The injection route includes the percutaneous, hepatic artery, and the combination with transarterial chemoembolization has also been tested and showed efficacy by improving the prognosis compared with Transarterial chemoembolization (TACE) monotherapy [47]. Administration of a dominant negative form of cyclin G1, also known as Rexin-G, using retroviral vector injection into the hepatic artery, has also been tested in the liver metastasis of colorectal tumors (NCT00035919) and has shown significant anti-tumor activity in pancreatic cancer [48]. At the basic level, other pro-apoptotic genes, such as Tumor necrosis factor (TNF)-related apoptosis-inducing ligand (TRAIL), have been tested to induce apoptosis in HCC cells. Adeno-associated virus (AAV)-human telomerase reverse transcriptase (hTERT)-TRAIL displayed cancer-specific cytotoxicity, and intratumoral administration of AAV-hTERT-TRAIL significantly suppressed tumor growth in a xenograft model $[15,49,50]$.

\subsubsection{Oncogenes}

A large number of the oncogenes related to HCC biology have been reported to date. The silencing of oncogenes has been tested in several studies using RNA interference (RNAi). Polo-like kinase 1 (PLK1) is a biomarker that can be used to evaluate the biological behavior and prognosis of the colorectal cancers [51] and is considered as an oncogene by cell cycle progression [52]. Indeed, siRNA against the PLK1 product using lipid nanoparticles (TKM-080301) has been tested (NCT01437007) for colorectal cancers with hepatic metastases by injecting into the hepatic artery [53]. Other oncogenes of ZEH2, Smad4, osteopontin, reptin, Nob1, LDHA, SNAIL, GRK2, ATAD2, and STIM1 have also been tested for the interference effect in basic studies [23]. Other potential target oncogenes, including Yes-associated protein [54], which is a member of the Hippo signaling pathway contributing to organ size control and tumorigenesis, have emerged as attractive targets for cancer therapeutics for liver cancer $[55,56]$. Survivin, which is a member of the family of apoptosis inhibitory proteins, has increased expression in various cancers [57] and, as a result, has been considered as a potential biomarker and therapeutic target for HCC gene therapy [58].

Various oligonucleotide-based gene therapies are used to target tumor suppressor genes and oncogenes [59]. Oligonulceotide-based therapies include mRNA [60], siRNA [61-63], miRNA [64], and non-coding RNA [65-69]. A siRNA [61-63] is a 20-24 bp double-stranded RNA produced by Dicer enzyme from long dsRNA or small hairpin RNA that knocks down genes by cleaving target mRNA with a complementary sequence before translation. The combination of siRNA and N-acetylgalactosamine (GalNAc) has been used to increase the efficacy of siRNA to enter the cytoplasm through binding to the asialoglycoprotein receptor, which is highly expressed on hepatocytes [70]. miRNA [64] is a 22 bp non-coding RNA that functions in RNA silencing and post-transcriptional regulation of gene expression, and is derived from short stem-loop RNA [71]. It has been reported that expression of miR-122 in HCC with poorly differentiated, large-sized, and invasive characteristics is frequently decreased and, therefore, the increase of miR-122 levels in those HCCs, with or without anti-tumor agents, showed promising anti-tumor effects for HCC [64]. Long non-coding RNAs (lncRNA) [65-69] are a group of 200 nucleotides on protein coding RNA that play an important role in transcription, translation, and protein modification as oncogenes or tumor suppressor genes. They are also involved in different epigenetic cellular processes, such as proliferation, differentiation, migration, invasion, and anti-apoptosis. The lncRNAs have been used to predict prognosis, and zinc finger protein 385D antisense RNA 2 (ZNF385DAS2) is a lncRNA that has been used to predict the prognosis of patients with several types of cancer, including liver cancers [67], and can be a useful therapeutic target [69]. 


\subsubsection{Suicide Gene Therapy}

Suicide gene therapy is based on the delivery of transgenes that convert prodrugs and are administered following gene delivery into cytotoxic metabolites and have shown anti-tumor effects [72]. The bystander effect of the cell-cell contact shows that cytotoxicity in the tumors cells neighboring the tumor cells is a characteristic of the therapy [72]. The most widely used combination of transgene and prodrug for HCC gene therapy is herpes simplex virus thymidine kinase (HSV-tk) and ganciclovir (GCV) [73-75]. Adenoviral vectors have been used to deliver HSV-tk injected either intravenously (NCT02202564, NCT00300521, and NCT03313596) or intratumorally (NCT00844623). Oncolytic virotherapy has also been reported for its anti-tumor effect [76] for various cancers including HCC and other liver tumors. Recently, oncolytic herpes simplex virus type-1 (HSV-1) has been tested for metastatic liver cancer from colorectal cancer (NV1020, NCT00012155) injected into the hepatic artery, and for HCC, other primary liver cancers, and metastatic liver tumors by administration via the hepatic artery (NCT01071941). The combinations of oncolytic virotherapy, other chemo-agents, and immune modifiers change the sensitivity of the tumor to the therapeutic options including immune checkpoint inhibition [77]. Thus, the suicide gene must be elicited in a tumor-specific manner using transcriptionally targeted retroviral replicating vectors [78], targeting genomic rearrangement in the tumor by genome-editing approach to insert the suicide gene [79]. One of the promising future targets includes diphtheria toxin $\mathrm{A}$, an immunotoxin, which has been widely used in gene therapy for its roles in protein synthesis inhibition [80]. This gene has also been used in pancreatic cancer [81,82], ovarian cancer [83], glioblastoma, HCC [84], and bladder cancer [85] using various delivery methods including an integrase-deficient lentiviral vector [80] and plasmid DNA [82,84,85].

\subsubsection{Tumor Proteins}

Glypican-3 (GPC-3) has also been tested to modify chimeric antigen receptor (CAR)-T-cells to treat HCC (NCT02715362, NCT03198546, and NCT02905188) administered through the hepatic artery, systemically, or by local injections. GPC-3 is a transmembrane heparan sulfate proteoglycan that regulates cell growth by tissue-dependent cellular signaling [86]; as its expression is increased in liver cancers, it has been used as a tumor maker and currently in ex vivo gene therapy to modify CAR-T to target HCC $[87,88]$. The alternative therapeutic option can be realizable in cases with p53-altered HCCs using aurora kinase A and the MYC complex based on results in xenograft models showing that p53-altered HCCs are hypersensitive with conformation-changed aurora kinase A [89]. The GPC-3-expressing T-cells have been tested for anti-tumor effects in pediatric liver cancers (NCT02932956) in combination with chemotherapy.

Alpha-fetoprotein (AFP) is one of the major tumor markers for HCC used in clinics [90] and are specific antigens presented on the cell surface [91]; thus, AFP is used for molecular targeting of CAR-T-cells for HCC (NCT03971747) in both ex vivo gene therapy and cancer vaccination (NCT00005629 and NCT03971747). With regard to cancer vaccination, intradermal injection of AFP peptide or adenoviral vector was used for HCC (NCT00093548). The safety and efficacy of AFP DNA prime and adenovirus boost immunization for HCC have also been tested [92].

Carcinoembryonic antigen (CEA) is useful for detecting recurrent metastatic colorectal cancers [93] as well as various CEA-related cell adhesion molecules [94]. As such, CEA has been used as a molecular target of CAR-T-cells in the treatment of liver metastases of colorectal cancers (NCT02416466, NCT02850536, and NCT00004178) and for developing T-cell therapy (NCT01373047) as an ex vivo gene therapy. These T-cells were administered via the hepatic artery, splenic vein, or veins. Further modification includes the administration of the vaccinia-CEA-mucin 1 triad of costimulatory molecules, and the TRICOM (PANVAC-V) vaccine has been tested for metastatic liver cancer from colorectal cancer (NCT00103142) [95].

Human epidermal growth factor receptor 2 (HER2) is a member of the epidermal growth factor family, and anti-HER2 treatment for HER2-positive breast cancer has shown promising efficacy [96]. Currently, a trial involving intravenous injection of an antibody drug conjugate 
targeting HER2-expressing cancers cells, including liver cancer and metastatic liver cancer, is ongoing (NCT03602079).

New York esophageal squamous cell carcinoma 1 (NY-ESO-1) is a cancer-testis antigen that is expressed in various cancer cells, and specific immune responses to it have been observed in various cancers [97]. NY-ESO-1 has been used in immune-based cancer therapy using genetically modified T-cells in clinics for NY-ESO-1 expressing solid tumors, including liver cancers (NCT02869217). Anti-NY-ESO-1 murine T cell receptor (TCR)-gene engineered lymphocytes have been administered intravenously for HCC and metastatic liver cancers from melanoma (NCT01967823).

\subsubsection{Genetic Immunotherapy}

Local expression of cytokine expression genes has been tested for anti-tumor efficacy, as the systemic administration of cytokines may result in severe adverse events [98]. The cytokines include interferon- $\beta$ expressed in an adenoviral vector injected intrapleurally for metastatic liver cancer (NCT00066404), expressed in a vesicular stomatitis viral vector injected intratumorally (NCT01628640) for advanced liver tumor, and interleukin-12 expressed in an adenoviral vector by intratumoral injection for liver metastasis from the breast cancer (NCT00301106) and for liver metastasis of colorectal cancer (NCT00072098). Autologous whole-cell tumor cell immunotherapy (FANG) has also been trialed (NCT01061840); this incorporates an intradermally injected plasmid encoding granulocyte macrophage colony-stimulating factor (GM-CSF) and a bifunctional short hairpin RNAi vector targeting furin convertase, thereby downregulating endogenous immunosuppressive transforming growth factors beta1 and beta2. Genetic immunotherapy also includes mRNA vaccination therapy; NCT03480152 is a clinical trial testing the efficacy of the anti-tumor effect of mRNA containing epitopes from immunogenic neoantigens, predicted neoantigens, and mutations in tumor suppressor or driver genes for HCC and metastatic liver tumors from colon cancer.

\subsection{Gene Delivery Procedures}

Studies focusing on gene delivery approaches for liver cancers have also been reported $[23,99,100]$. Gene delivery procedures can be classified into viral gene delivery, non-viral gene delivery using chemical compounds, and non-viral gene delivery using physical methods [101-103]. Various gene delivery procedures used in these studies are summarized in Table 1 and Figure 1 to understand the advantages and disadvantages of each procedure, which will help to develop the novel methods of delivery. 


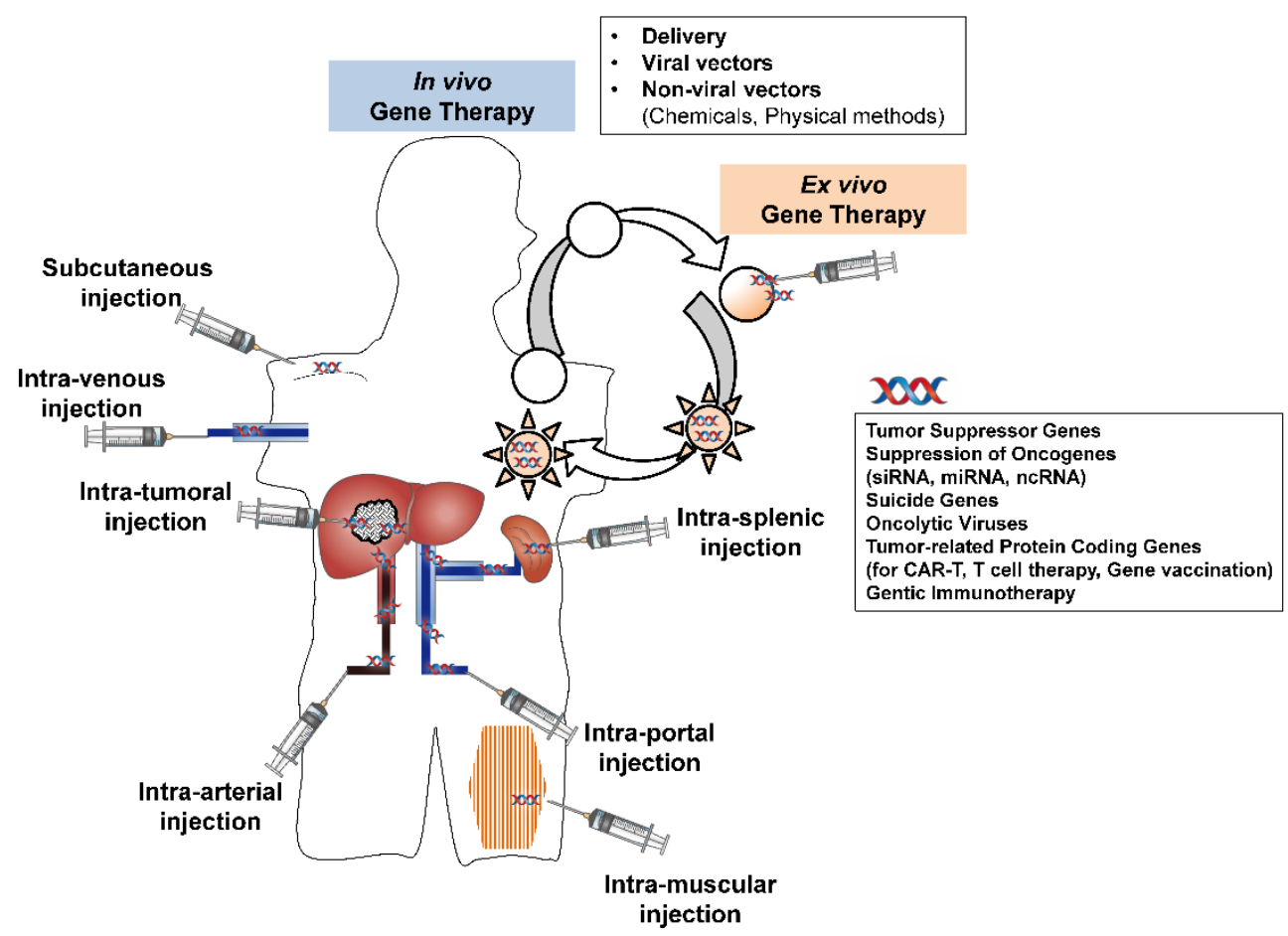

Figure 1. Schematic summary of gene therapy strategies for liver cancers. siRNA: small interfering RNA, miRNA: microRNA, ncRNA: non-coding RNA, CAR-T: chimeric antigen receptor-T-cell.

\subsubsection{Viral Gene Delivery}

Clinically, more than $67 \%$ of gene therapy clinical trials have been conducted using viral vectors [28]. A virus-based gene delivery system represents a group of artificially made, replication-deficient viruses [104,105]; the most commonly used virus-based gene delivery systems are adeno-associated viral vectors [49,106], lentiviral vectors [105,107], adenoviral vectors [105,108], foamy viral vectors [109], herpes simplex viral vectors [110], oncoretroviral vectors [105], and cytomegaloviral vectors [111]. Among them, AAV vectors are often used; these are derived from the parvovirus and have a single-stranded DNA genome of approximately $4.7 \mathrm{~kb}$. There are two genes in viral genome DNA, rep and cap, encoding seven major transcription units, Rep40, Rep52, Rep68, Rep78, VP1, VP2, and VP3 [112]. There are several serotypes of AAV, and it is worth noting that each serotype of AAV has a unique approach for infecting host cells. Single-stranded DNA is converted to the double-stranded vector genome from which the transgene is expressed. The target organ preference depends on the infectivity of wild serotype to those organs, and AAV-8 preferentially transduces into hepatocytes [113]; thus, AAV-8 is suitable for liver-targeted gene therapy intended for treatment of citrullinemia [114], hemophilia [115,116], alpha 1-antitrypsin deficiency [117], and viral hepatitis diseases [118].

The first gene therapy studies using AAV for HCC were reported by Su H, et al. using the HSV-tk gene driven by an AFP enhancer and the albumin promoter. They showed AFP-positive cell-specific tumor cell suppression that inspired a number of subsequent studies and trials [119]. In most of the studies, viral vector-mediated gene delivery to the liver was achieved via the hepatic artery [120,121], portal vein [122,123], bile duct [122], or by direct injection to the liver [122]. Interestingly, the clinical studies revealed the efficacy of positron emission tomography imaging the intratumoral injection of adenoviral vector for HCC [124]. Overall, however, viral vector-induced carcinogenesis and immunogenicity is currently a major hurdle for viral vector-mediated gene therapy.

\subsubsection{Non-Viral Gene Delivery Using Chemicals}

Compared with viral vectors that employ their natural ability to transfer genes into cells, non-viral gene delivery systems use physical force or the cellular function of endocytosis to facilitate gene 
transfer to target cells $[102,125]$. Clinically, $21 \%$ of gene therapy clinical trials have been conducted using non-viral vectors [28]. The major challenge for non-viral vector-mediated gene delivery is its relatively low efficiency.

Non-viral vectors using chemicals include synthetic or natural compounds that are capable of forming complexes with plasmid DNA or gene coding fragments and facilitating intracellular gene transfer. Materials including lipids [126], polymers [127], proteins [128], and peptides [128] have been shown to be effective for gene delivery to tissues [129,130] and in HCC [131]. Non-viral vectors have been evaluated for gene therapy of a variety of liver diseases including hepatic fibrosis, viral hepatitis, and liver cancer [24]. Taking advantage of membrane receptors on hepatic stellate cells, liver-targeted gene delivery for hepatic fibrosis has been attempted using the mannose 6-phosphate/insulin-like growth factor-II receptor [132-134], integrins [135], high-affinity membrane receptor for retinol-binding protein, and the galactosyl receptor as targets [101]. Target-specific gene delivery is a desirable feature, and polymeric nanoparticles [131] targeting cancer-specific DNA have shown promising anti-tumor effects in vitro and in vivo [136]. A cationic solid lipid nanoparticle also showed effective inhibition of HCC growth by delivering shRNA for the NURP gene [137], and similarly, siRNA to PLK1 gene delivered by chitosan nanoparticles efficiently suppressed HCC cell growth both in vitro and in vivo [138]. Gold nanoparticles, which have been used as attractive chemical vehicles for the gene delivery [139], and are currently used for gene editing [140], have also been tested for their applicability in HCC gene therapy in vivo, owing to their ability to modify the surface to attach multiple ligands, their superior visibility, and their low cytotoxicity [141].

Recently, the integrins and heparan sulfate proteoglycans on hepatic stellate cells have been considered as receptors for exosomes [142]. Exosomes are small membranous vesicles released by most cells, including tumor cells that contain biological molecules, such as non-coding RNAs, and participate in regulating tumor development, metastasis, and drug resistance. Therefore, exosomal components have emerged as potential biomarkers, and exosomes can serve as natural vehicles to deliver non-coding RNA for treatment [69]. Exosomal components may be a next-generation non-viral delivery procedure, and further assessment is essential.

\subsubsection{Non-Viral Gene Delivery Using Physical Methods}

Physical methods of gene delivery employ a physical force to overcome the membrane barrier of a cell. Compared with viral and chemical vector-mediated gene delivery, physical approaches do not involve any cytotoxic or immunogenic substances. Physical methods employed for gene delivery include needle injection, gene gun, electroporation, sonoporation, and hydrodynamic gene delivery [102]. Among these methods, sonoporation has shown potential to express pro-apoptotic genes in HCC cells in vitro [143] and deliver shRNA of frizzled-2 to suppress HCC in vitro [144]. Electroporation has been used for delivering TRAIL/Apo2L gene to induce apoptosis [145]; the IL-12 gene to induce immune responses to HCC $[146,147]$; more recently, to deliver mRNA into T-cells to develop specific T-cells for HCC immunotherapy [148]; and GPC-3 CAR-T-cells [149]. Magnetofection has also been used to deliver genes into HCC cell lines combined with ternary organic-inorganic hybrid nanocomposites containing deferoxamine-coated iron oxide nanoparticles, plasmid DNA, and branched polyethyleneimine [150]. Hydrodynamic gene delivery has been used for functional analysis of therapeutic genes and regulatory elements in rodents since its establishment in 1999 [151,152]. Efforts have been made in developing a clinically applicable procedure for hydrodynamic gene delivery to the liver. For instance, Kamimura et al. examined a catheter insertion technique to the hepatic lobular vein for site-specific, safe, and efficient gene delivery in pigs and dogs $[153,154]$. This procedure has shown therapeutic effect in liver fibrosis $[155,156]$, and recently in HCC in mice driven by AKT over expression delivering a dominant negative form of heat shock transcription factor 1 [157]. The challenges for non-viral gene delivery are the lower efficiency of gene delivery compared with viral vectors, although target/tumor-specific gene delivery can be achieved better than viral vectors. The combination of these viral and non-viral gene delivery procedures might be effective, as evidenced 
in the recent reports showing that polyethyleneimine, ultrasound, and nanobubbles can effectively deliver shRNA in liver cancer [158].

To further extend the tumor-specific gene delivery, various gene delivery routes have been tested including intratumoral injection, intrasplenic injection, intra-arterial injection, intravenous injection, intraportal injection, intramuscular injection, subcutaneous injection, oral injection, and liver incisal margin injection [23]. In addition, promoter selective gene expression is another method of HCC-specific gene delivery, and the AFP promoter has been used to induce HSV-tk gene using the AAV vector [119].

\subsection{Clinical Trials}

Conventional diagnostic strategies, such as computed tomography and biopsies, as well as the development of molecular biology and techniques such as new generation sequencing and single cell analyses, have significantly contributed to the understanding of the pathogenesis of liver cancer and provided novel therapeutic options. On the basis of the progress of gene therapy described above, various clinical trials are ongoing [28] and gene therapy has become a realistic treatment option for a wide variety of cancers $[25,26]$.

\subsubsection{Ongoing Clinical Trials for Gene Therapy of Liver Cancers}

The summary of the results of several completed and ongoing clinical trials for HCC is shown in Table 2 and Supplementary Table S1. Building on preclinical studies, several clinical trials have been conducted to evaluate gene therapy for liver cancers [53,73,74,87,92,95,124,159-167]. A summary of these studies as of October 2019 can be found in Table 2 and Supplementary Table S1. The description of genes used has been outlined in the previous sections. Adenoviruses [73,124,165], oncolytic herpes simplex viruses (NCT00012155) [74], retroviruses, plasmids, and synthetic vectors were used to deliver tumor suppressor genes, suicide genes (NCT00844623) [73,124], cytokine genes, or antigens (peptides) for the anti-tumor effect and for cancer vaccination (NCT03480152) [87,92,159-161]. Moreover, T-cells (NCT01967823) [162-164] and CAR-T-cells (NCT03198546) [87] have been used in ex vivo gene therapy to induce tumor cell-specific immune responses. These vectors and cells have been delivered by percutaneous, intrahepatic arterial injection, intravenous injection, intrasplenic venous injection, intratumoral injection, intramuscular injection, intrapleural injection, and intradermal injection. In addition, some studies have combined gene delivery with the traditional therapeutic option of transarterial embolization (TAE) for HCC injecting genes into the embolized artery following TAE. Among the 34 clinical trials in which information is registered, only one was a phase III study, and the remaining studies were phase I or II. The phase III trial was a multicenter randomized controlled trial of adenovirus-mediated adjuvant gene therapy for patients with HCC who received liver transplantation. The study compared the effect of liver transplantation plus adenovirus-mediated suicide gene therapy versus transplantation in advanced primary HCC (NCT03313596). To date, 180 cases were enrolled, and the trial will be completed in December 2019. The genes transferred include genes encoding p53, TK of herpes simplex virus (HSV-tk), AFP (NCT00093548) [92], interferon-beta (NCT00066404) [165], interleukin-12, dominant negative form of cyclin G1, HER-2, GM-CSF (NCT01061840) [166,167], CEA, glypican 3-specific chimeric antigen (NCT03198546) [87], mRNA containing epitopes from immunogenic neoantigens, predicted neoantigens and mutations in tumor suppressor or driver genes [159-161], and autoimmunogenic cancer/testis antigen New York esophageal squamous cell carcinoma 1 (NY-ESO-1) [162-164]. The phase II gene vaccination study has been tested for its anti-tumor effect in metastatic liver cancer genes (NCT00103142). In addition, other oligonucleotides, including short hairpin RNA combined with a GM-CSF expressing plasmid [166,167], as well as short interfering RNA against polo-like kinase 1 (PLK-1) gene products carried by lipid nanoparticles (NCT01437007) [53], have also been tested. While detailed information is available for 34 studies, only a few results have been reported to date and the remainder of the study is mostly under assessment (Table 2 and Supplementary Table S1). NCT00844623 showed the safety and the potential anti-tumor 
efficacy of HSVtk gene using adenoviral vector in phase 1 study [73]. Further, related to NCT01967823, TCR-based gene therapies against NY-ESO-1 showed anti-tumor effect in the metastatic melanoma tumors [164]. NCT00012155 reported its results, showing that the NV1020, oncolytic HSV-1, can be safely administered into the hepatic artery of the cases with metastatic colorectal carcinoma to the liver [74]. A phase I trial of hIFN-beta gene using the adenoviral vector for the metastatic liver tumors (NCT0006640) showed safety and disease stability of the approach, although the rapid development of antibody to the vector was revealed to be the issue [165]. Furthermore, although the clinical trial (NCT00093548) was withdrawn, gene vaccination using AFP gene showed better progression-free survival [92]. The phase 1 trial of bi-shRNAi(furin)/GMCSF DNA/autologous tumor cell vaccine (NCT01061840) showed its safety [167]. A hepatic arterial infusion of lipid nanoparticles containing siRNA against the PLK1 gene product showed potential usefulness of the product for the metastatic liver tumors [53]. NCT00103142 showed the anti-tumor effect for the metastatic liver tumors of gene vaccination using autologous dendritic cells in the phase 2 study. Although NCT3480152 has a background of basic studies showing the importance of TCR affinity and tumor specific CD4 $4^{+} \mathrm{T}$ cells in tumor immunotherapy for HCC and metastatic liver tumors [159], and NCT03198546 has a background of successful suppression of HCC growth in the basic research [87], no clinical results have been reported to date for these trials.

\subsubsection{Ongoing Clinical Trials for Gene-Based Diagnosis}

The summary of clinical trials for the molecular-based diagnosis and to determine the genetic background relating to chemosensitivity are shown in Table 3. The investigation of molecular tumor features is essential in order to efficiently translate the results of basic research. For this purpose, genetic analyses of liver tissues from patients with HCC for genomic medicine have provided important information about tumor initiation, progression, and chemosensitivity [168]. The findings from these studies can be used to develop personalized gene-based therapy and genome-based diagnosis in the tumor; therefore, various clinical trials to determine the disease activity and sensitivity to the specific therapy are ongoing [169-173]. One of the trials bridged into the phase $1 / 2$ trial is NCT03480152, examining the effect of mRNA cancer vaccine, delivering mRNA containing epitopes from immunogenic neoantigens, predicted neoantigens, and mutations in tumor suppressor or driver genes, by intramuscular injection [159-161]. A summary of these studies as of October 2019 can be found in Table 3. Among the 14 clinical trials in which information is registered, only one was a phase IV study, and the remaining studies were phase I or II. The phase IV study assessed the mechanism of sorafenib resistance in patients with HCC [169]. 
Table 2. Summary of ongoing clinical trials for gene therapy for liver cancers

\begin{tabular}{|c|c|c|c|c|c|c|c|c|c|c|}
\hline No & $\begin{array}{c}\text { NCT } \\
\text { Number }\end{array}$ & $\begin{array}{l}\text { Types of Liver } \\
\text { Tumors }\end{array}$ & Gene/Antigen & $\begin{array}{l}\text { Types of } \\
\text { Gene }\end{array}$ & Vectors or Cells & Intervention & $\begin{array}{c}\text { Route of } \\
\text { Administration }\end{array}$ & Phase & $\begin{array}{c}\text { Current Status and } \\
\text { Results }\end{array}$ & Ref. \\
\hline 1 & NCT00003147 & $\mathrm{HCC}$ & p53 & & Adenoviral Vector & $\begin{array}{l}\text { Ad5CMV-p53 } \\
\text { gene }\end{array}$ & $\begin{array}{l}\text { Percutaneous } \\
\text { injection }\end{array}$ & 1 & $\begin{array}{c}\text { Terminated No results } \\
\text { available }\end{array}$ & \\
\hline \multirow[t]{2}{*}{2} & NCT01071941 & $\begin{array}{l}\text { Primary Liver } \\
\text { Cancers }\end{array}$ & Oncolytic Virus & $\begin{array}{l}\text { Oncolytic } \\
\text { Virus }\end{array}$ & $\begin{array}{l}\text { Herpes simplex virus } \\
1\end{array}$ & rRp450 & $\begin{array}{l}\text { Hepatic arterial } \\
\text { injection }\end{array}$ & 1 & $\begin{array}{l}\text { Recruiting No results } \\
\text { available Estimated } \\
\text { Completion Date: July, } \\
2020\end{array}$ & \\
\hline & & $\begin{array}{l}\text { Metastatic Liver } \\
\text { Tumors }\end{array}$ & & & & & & & & \\
\hline 3 & NCT00844623 & $\mathrm{HCC}$ & HSVtk & Suicide & Adenoviral vector & $\begin{array}{c}\text { TK99UN } \\
\text { (adenoviral } \\
\text { vector } \\
\text { containing TK) }\end{array}$ & $\begin{array}{l}\text { Intratumoral } \\
\text { injection }\end{array}$ & 1 & $\begin{array}{l}\text { Completed Results } \\
\text { partly reported. }\end{array}$ & {$[73,124]$} \\
\hline 4 & NCT02202564 & $\mathrm{HCC}$ & HSVtk & Suicide & Adenoviral vector & $\begin{array}{l}\text { LT ADV-TK } \\
\text { ganciclovir }\end{array}$ & $\begin{array}{c}\text { Intravenous } \\
\text { infusion }\end{array}$ & 2 & $\begin{array}{l}\text { Completed No results } \\
\text { reported to date }\end{array}$ & \\
\hline 5 & NCT02561546 & HCC & p53 & $\begin{array}{c}\text { Tumor } \\
\text { suppressor }\end{array}$ & $\begin{array}{l}\text { Recombinant } \\
\text { adenoviral vector }\end{array}$ & $\begin{array}{c}\text { p53 gene } \\
\text { therapy TAE }\end{array}$ & $\begin{array}{l}\text { Hepatic arterial } \\
\text { injection } \\
\text { following TAE }\end{array}$ & 2 & Not yet recruiting & \\
\hline 6 & NCT00300521 & $\mathrm{HCC}$ & HSVtk & Suicide & Adenoviral vector & ADV-TK & $\begin{array}{l}\text { Intravenous } \\
\text { infusion }\end{array}$ & 2 & $\begin{array}{l}\text { Completed No results } \\
\text { reported to date }\end{array}$ & \\
\hline 7 & NCT00004178 & $\begin{array}{l}\text { Primary Liver } \\
\text { Cancers } \\
\text { Metastatic Liver } \\
\text { Tumors }\end{array}$ & CEA & $\begin{array}{l}\text { Tumor-related } \\
\text { Protein } \\
\text { Coding }\end{array}$ & $\begin{array}{c}\text { T Cells Modified with } \\
\text { Chimeric Anti-CEA } \\
\text { Immunoglobulin-T } \\
\text { Cell Receptors } \\
\text { (IgTCR) in } \\
\text { Adenocarcinoma }\end{array}$ & $\begin{array}{l}\text { Therapeutic } \\
\text { autologous } \\
\text { lymphocytes }\end{array}$ & $\begin{array}{l}\text { Intravenous } \\
\text { infusion }\end{array}$ & 1 & $\begin{array}{l}\text { Completed No results } \\
\text { reported to date }\end{array}$ & \\
\hline 8 & NCT03313596 & $\mathrm{HCC}$ & HSVtk & Suicide & Adenoviral vector & ADV-TK LT & $\begin{array}{l}\text { Intravenous } \\
\text { infusion }\end{array}$ & 3 & $\begin{array}{c}\text { Recruiting No results } \\
\text { available Estimated } \\
\text { Completion Date: Dec, } \\
2019\end{array}$ & \\
\hline \multirow[t]{2}{*}{9} & NCT03480152 & $\begin{array}{l}\text { Primary Liver } \\
\text { Cancers }\end{array}$ & $\begin{array}{l}\text { mRNA containing epitopes } \\
\text { from immunogenic } \\
\text { neoantigens }\end{array}$ & $\begin{array}{l}\text { Tumor-related } \\
\text { Protein } \\
\text { Coding }\end{array}$ & mRNA vaccine & $\begin{array}{c}\text { NCI-4650, a } \\
\text { mRNA-based, } \\
\text { Personalized } \\
\text { Cancer Vaccine }\end{array}$ & $\begin{array}{l}\text { Intramuscular } \\
\text { injection }\end{array}$ & $1 / 2$ & \multirow[t]{2}{*}{$\begin{array}{l}\text { Terminated Related } \\
\text { results partly reported }\end{array}$} & [159-161] \\
\hline & & $\begin{array}{l}\text { Metastatic Liver } \\
\text { Tumors }\end{array}$ & $\begin{array}{l}\text { mRNA containing epitopes } \\
\text { from immunogenic } \\
\text { predicted neoantigens }\end{array}$ & & & & & & & \\
\hline
\end{tabular}


Table 2. Cont.

\begin{tabular}{|c|c|c|c|c|c|c|c|c|c|c|}
\hline No & $\begin{array}{c}\text { NCT } \\
\text { Number }\end{array}$ & $\begin{array}{l}\text { Types of Liver } \\
\text { Tumors }\end{array}$ & Gene/Antigen & $\begin{array}{l}\text { Types of } \\
\text { Gene }\end{array}$ & Vectors or Cells & Intervention & $\begin{array}{c}\text { Route of } \\
\text { Administration }\end{array}$ & Phase & $\begin{array}{c}\text { Current Status and } \\
\text { Results }\end{array}$ & Ref. \\
\hline & & & $\begin{array}{l}\text { mRNA containing epitopes } \\
\text { from immunogenic } \\
\text { mutations in tumor } \\
\text { suppressor or driver genes }\end{array}$ & & & & & & & \\
\hline 10 & NCT01967823 & $\begin{array}{l}\text { HCC Metastatic } \\
\text { Liver Tumors }\end{array}$ & NY-ESO-1 & $\begin{array}{l}\text { Tumor-related } \\
\text { Protein } \\
\text { Coding }\end{array}$ & $\begin{array}{l}\text { Anti-NY ESO-1 } \\
\text { Murine TCR-Gene } \\
\text { Engineered } \\
\text { Lymphocytes }\end{array}$ & $\begin{array}{l}\text { Anti-NY ESO-1 } \\
\text { mTCR PBL } \\
\text { Cyclophosphamide } \\
\text { Fludarabine } \\
\text { Aldesleukin } \\
\end{array}$ & $\begin{array}{l}\text { Intravenous } \\
\text { infusion }\end{array}$ & 2 & $\begin{array}{c}\text { Recruiting No results } \\
\text { available Estimated } \\
\text { Completion Date: July, } \\
2028\end{array}$ & [162-164] \\
\hline 11 & NCT02509169 & $\mathrm{HCC}$ & p53 & $\begin{array}{l}\text { Tumor } \\
\text { suppressor }\end{array}$ & $\begin{array}{l}\text { Recombinant } \\
\text { adenoviral vector }\end{array}$ & $\begin{array}{l}\text { TAE plus P53 gene } \\
\text { TAE }\end{array}$ & $\begin{array}{c}\text { Hepatic arterial } \\
\text { injection } \\
\text { following TAE }\end{array}$ & 2 & $\begin{array}{l}\text { Recruiting No results } \\
\text { available }\end{array}$ & \\
\hline 12 & NCT02932956 & $\begin{array}{l}\text { Pediatric Primary } \\
\text { Liver Cancers }\end{array}$ & GPC-3 & $\begin{array}{l}\text { Tumor-related } \\
\text { Protein } \\
\text { Coding }\end{array}$ & CAR T cells & $\begin{array}{c}\text { GAP T cells } \\
\text { Cytoxan Fludara }\end{array}$ & & 1 & $\begin{array}{c}\text { Recruiting No results } \\
\text { available Estimated } \\
\text { Completion Date: Feb, } \\
2037 \\
\end{array}$ & \\
\hline 13 & NCT00012155 & $\begin{array}{l}\text { Metastatic Liver } \\
\text { Tumors }\end{array}$ & Oncoytic Virus & $\begin{array}{l}\text { Oncoytic } \\
\text { Virus }\end{array}$ & $\begin{array}{l}\text { oncolytic herpes } \\
\text { simplex virus } \\
\text { type-1(HSV-1) }\end{array}$ & $\begin{array}{l}\text { NV1020, oncolytic } \\
\text { herpes simplex } \\
\text { virus type-1 (HSV-1) }\end{array}$ & $\begin{array}{l}\text { Hepatic arterial } \\
\text { injection }\end{array}$ & 1 & $\begin{array}{l}\text { Completed Results } \\
\text { partly reported }\end{array}$ & [74] \\
\hline 14 & NCT00066404 & $\begin{array}{l}\text { Metastatic Liver } \\
\text { Tumors }\end{array}$ & Interferon-beta & $\begin{array}{c}\text { Genetic } \\
\text { Immunotherapy }\end{array}$ & Adenoviral vector & $\begin{array}{c}\text { recombinant } \\
\text { adenovirus-hIFN-beta }\end{array}$ & $\begin{array}{c}\text { Intrapleural } \\
\text { injection }\end{array}$ & 1 & $\begin{array}{l}\text { Active, not recruiting } \\
\text { Results partly reported }\end{array}$ & [165] \\
\hline 15 & NCT00035919 & $\begin{array}{l}\text { Metastatic Liver } \\
\text { Tumors } \\
\end{array}$ & $\begin{array}{c}\text { Dominant Negative Cyclin } \\
\text { G1 }\end{array}$ & $\begin{array}{c}\text { Tumor } \\
\text { suppressor }\end{array}$ & Retroviral Vector & $\begin{array}{l}\text { Mx-dnG1 Retroviral } \\
\text { Vector }\end{array}$ & $\begin{array}{c}\text { Hepatic arterial } \\
\text { infusion }\end{array}$ & $1 / 2$ & Withdrawn & \\
\hline 16 & NCT00005629 & $\begin{array}{l}\text { Primary Liver } \\
\text { Cancers } \\
\text { Metastatic Liver } \\
\text { Tumors } \\
\end{array}$ & AFP & $\begin{array}{l}\text { Tumor-related } \\
\text { Protein } \\
\text { Coding }\end{array}$ & AFP peptide & $\begin{array}{c}\text { AFP gene } \\
\text { hepatocellular } \\
\text { carcinoma vaccine }\end{array}$ & $\begin{array}{l}\text { Intradermal } \\
\text { injection }\end{array}$ & $1 / 2$ & $\begin{array}{l}\text { Completed No results } \\
\text { reported to date }\end{array}$ & \\
\hline 17 & NCT02905188 & HCC & GPC-3 & $\begin{array}{l}\text { Tumor-related } \\
\text { Protein } \\
\text { Coding }\end{array}$ & CAR T cells & GLYCAR T cells & $\begin{array}{l}\text { Intravenous } \\
\text { infusion }\end{array}$ & 1 & $\begin{array}{c}\text { Recruiting No results } \\
\text { available Estimated } \\
\text { Completion Date: Oct, } \\
2036\end{array}$ & \\
\hline 18 & NCT00093548 & HCC & AFP, GM-CSF & $\begin{array}{l}\text { Tumor-related } \\
\text { Protein } \\
\text { Coding }\end{array}$ & Adenoviral vector & $\begin{array}{c}\text { Vaccination AFP } \\
\text { plasmid DNA } \\
\text { vaccine GM-CSF } \\
\text { plasmid DNA } \\
\text { hepatocellular } \\
\text { carcinoma vaccine } \\
\text { adjuvant }\end{array}$ & $\begin{array}{l}\text { Intramuscular } \\
\text { injection/Intradermal } \\
\text { injection }\end{array}$ & $1 / 2$ & Withdrawn & [92] \\
\hline
\end{tabular}


Table 2. Cont

\begin{tabular}{|c|c|c|c|c|c|c|c|c|c|c|}
\hline No & $\begin{array}{c}\text { NCT } \\
\text { Number }\end{array}$ & $\begin{array}{l}\text { Types of Liver } \\
\text { Tumors }\end{array}$ & Gene/Antigen & $\begin{array}{l}\text { Types of } \\
\text { Gene }\end{array}$ & Vectors or Cells & Intervention & $\begin{array}{c}\text { Route of } \\
\text { Administration }\end{array}$ & Phase & $\begin{array}{c}\text { Current Status and } \\
\text { Results }\end{array}$ & Ref. \\
\hline 19 & NCT01628640 & $\begin{array}{l}\text { Primary Liver } \\
\text { Cancers } \\
\text { Metastatic Liver } \\
\text { Tumors }\end{array}$ & Interferon-beta & $\begin{array}{l}\text { Genetic } \\
\text { Immunotherapy }\end{array}$ & $\begin{array}{l}\text { Vesicular Stomatitis } \\
\text { Virus }\end{array}$ & $\begin{array}{l}\text { Recombinant } \\
\text { Vesicular } \\
\text { Stomatitis } \\
\text { Virus-expressing } \\
\text { Interferon-beta }\end{array}$ & $\begin{array}{l}\text { Intratumoral } \\
\text { Injection }\end{array}$ & 1 & $\begin{array}{l}\text { Active, not recruiting } \\
\text { Estimated Completion } \\
\text { Date: June, } 2025\end{array}$ & \\
\hline 20 & NCT03602079 & $\begin{array}{c}\text { HCC CCC } \\
\text { Metastatic Liver } \\
\text { Tumors }\end{array}$ & HER-2 & $\begin{array}{l}\text { Tumor-related } \\
\text { Protein } \\
\text { Coding }\end{array}$ & $\begin{array}{l}\text { Antibody Drug } \\
\text { Conjugate (ADC) }\end{array}$ & $\begin{array}{c}\text { A166, an } \\
\text { Antibody Drug } \\
\text { Conjugate } \\
\text { (ADC) targeting } \\
\text { HER2 } \\
\text { expressing } \\
\text { cancer cells. }\end{array}$ & $\begin{array}{l}\text { Intravenous } \\
\text { infusion }\end{array}$ & $1 / 2$ & $\begin{array}{c}\text { Recruiting No results } \\
\text { available Estimated } \\
\text { Completion Date: May, } \\
2021\end{array}$ & \\
\hline 21 & NCT02416466 & $\begin{array}{l}\text { Metastatic Liver } \\
\text { Tumors }\end{array}$ & CEA & $\begin{array}{l}\text { Tumor-related } \\
\text { Protein } \\
\text { Coding }\end{array}$ & CAR-T cells & $\begin{array}{l}\text { anti-CEA } \\
\text { CAR-T cells }\end{array}$ & $\begin{array}{l}\text { Hepatic arterial } \\
\text { infusion }\end{array}$ & 1 & $\begin{array}{l}\text { Completed No results } \\
\text { reported to date }\end{array}$ & \\
\hline 22 & NCT02869217 & $\begin{array}{c}\text { NY-ESO-1 } \\
\text { Expressing Liver } \\
\text { Cancers in } \\
\text { HLA-A2 Positive } \\
\text { Patients } \\
\text { Metastatic Liver } \\
\text { Tumors }\end{array}$ & NY-ESO-1 & $\begin{array}{l}\text { Tumor-related } \\
\text { Protein } \\
\text { Coding }\end{array}$ & $\begin{array}{l}\text { NY-ESO-1 Specific } \\
\text { TCR Gene } \\
\text { Transduced } \\
\text { Autologous T } \\
\text { Lymphocytes }\end{array}$ & $\begin{array}{c}\text { TBI-1301 } \\
\text { (NY-ESO-1 } \\
\text { Specific TCR } \\
\text { Gene } \\
\text { Transduced } \\
\text { Autologous T } \\
\text { Lymphocytes) } \\
\text { Cyclophosphamide }\end{array}$ & Infusion & 1 & $\begin{array}{c}\text { Recruiting No results } \\
\text { available Estimated } \\
\text { Completion Date: June, } \\
2020\end{array}$ & \\
\hline 23 & NCT01061840 & $\begin{array}{c}\text { Primary Liver } \\
\text { Cancers } \\
\text { Metastatic Liver } \\
\text { Tumors } \\
\end{array}$ & $\begin{array}{l}\text { rhGMCSF and } \\
\text { bi-shRNAfurin from the } \\
\text { Vigili }{ }^{\mathrm{TM}} \text { plasmid }\end{array}$ & $\begin{array}{l}\text { Tumor-related } \\
\text { Protein } \\
\text { Coding }\end{array}$ & plasmid & Vaccination & $\begin{array}{l}\text { Intradermal } \\
\text { injection }\end{array}$ & 1 & $\begin{array}{l}\text { Completed Results } \\
\text { partly reported }\end{array}$ & {$[166,167]$} \\
\hline 24 & NCT01437007 & $\begin{array}{l}\text { Metastatic Liver } \\
\text { Tumors from } \\
\text { Colorectal, } \\
\text { Pancreas, Gastric, } \\
\text { Breast, and } \\
\text { Ovarian Cancers }\end{array}$ & siRNA Against the PLK1 & $\begin{array}{c}\text { Oncogene } \\
\text { suppression }\end{array}$ & Lipid Nanoparticles & TKM-080301 & $\begin{array}{l}\text { Hepatic arterial } \\
\text { infusion }\end{array}$ & 1 & $\begin{array}{l}\text { Completed Results } \\
\text { partly reported }\end{array}$ & [53] \\
\hline 25 & NCT03971747 & $\mathrm{HCC}$ & AFP & $\begin{array}{l}\text { Tumor-related } \\
\text { Protein } \\
\text { Coding }\end{array}$ & T Cell & $\begin{array}{l}\text { AFP Specific T } \\
\text { Cell Receptor T } \\
\text { Cells }\end{array}$ & $\begin{array}{l}\text { Intravenous } \\
\text { infusion }\end{array}$ & 1 & Not yet recruiting & \\
\hline 26 & NCT02418988 & $\mathrm{HCC}$ & p53 & $\begin{array}{l}\text { Tumor } \\
\text { suppressor }\end{array}$ & $\begin{array}{l}\text { Recombinant } \\
\text { adenoviral vector }\end{array}$ & $\begin{array}{l}\text { TACE plus } \\
\text { rAd-p53 artery } \\
\text { injection TACE }\end{array}$ & $\begin{array}{l}\text { Injected into the } \\
\text { embolization } \\
\text { artery. }\end{array}$ & 2 & $\begin{array}{l}\text { Recruiting No results } \\
\text { available }\end{array}$ & \\
\hline
\end{tabular}


Table 2. Cont.

\begin{tabular}{|c|c|c|c|c|c|c|c|c|c|c|}
\hline No & $\begin{array}{c}\text { NCT } \\
\text { Number }\end{array}$ & $\begin{array}{c}\text { Types of Liver } \\
\text { Tumors }\end{array}$ & Gene/Antigen & Types of Gene & Vectors or Cells & Intervention & $\begin{array}{c}\text { Route of } \\
\text { Administration } \\
\end{array}$ & Phase & $\begin{array}{c}\text { Current Status and } \\
\text { Results }\end{array}$ & Ref \\
\hline 27 & NCT02850536 & $\begin{array}{l}\text { Metastatic Liver } \\
\text { Tumors from } \\
\text { Colorectal, Pancreas, } \\
\text { Gastric, Breast, and } \\
\text { Ovarian Cancers }\end{array}$ & CEA & $\begin{array}{l}\text { Tumor-related } \\
\text { Protein Coding }\end{array}$ & CAR-T cells & $\begin{array}{l}\text { anti-CEA } \\
\text { CAR-T cells }\end{array}$ & $\begin{array}{l}\text { Hepatic arterial } \\
\text { infusion or } \\
\text { splenic vein }\end{array}$ & 1 & $\begin{array}{l}\text { Active, not recruiting } \\
\text { Estimated Completion } \\
\text { Date: Dec, } 2019\end{array}$ & \\
\hline 28 & NCT01373047 & $\begin{array}{l}\text { Metastatic Liver } \\
\text { Tumors from } \\
\text { Colorectal, Pancreas, } \\
\text { Gastric, Breast, and } \\
\text { Ovarian Cancers }\end{array}$ & CEA & $\begin{array}{l}\text { Tumor-related } \\
\text { Protein Coding }\end{array}$ & $\mathrm{T}$ cell & $\begin{array}{l}\text { anti-CEA 2nd } \\
\text { generation } \\
\text { designer T cells }\end{array}$ & $\begin{array}{l}\text { Hepatic arterial } \\
\text { infusion or } \\
\text { splenic vein }\end{array}$ & 1 & $\begin{array}{l}\text { Completed No results } \\
\text { reported to date }\end{array}$ & \\
\hline 29 & NCT02432963 & $\begin{array}{l}\text { Adult Solid } \\
\text { Neoplasm }\end{array}$ & p53 & $\begin{array}{c}\text { Tumor } \\
\text { suppressor }\end{array}$ & $\begin{array}{l}\text { Modified vaccinia } \\
\text { virus }\end{array}$ & Vaccination & & 1 & $\begin{array}{l}\text { Active, not recruiting } \\
\text { Estimated Completion } \\
\text { Date: Feb, } 2020\end{array}$ & \\
\hline 30 & NCT02715362 & $\mathrm{HCC}$ & GPC3 & $\begin{array}{c}\text { Tumor-related } \\
\text { Protein Coding }\end{array}$ & CAR-T cells & $\begin{array}{l}\text { TAI-GPC3-CART } \\
\text { cells }\end{array}$ & $\begin{array}{l}\text { Hepatic arterial } \\
\text { infusion }\end{array}$ & $1 / 2$ & $\begin{array}{c}\text { Recruiting No results } \\
\text { available }\end{array}$ & \\
\hline 31 & NCT00301106 & $\begin{array}{l}\text { Metastatic Liver } \\
\text { Tumors from } \\
\text { Colorectal, Pancreas, } \\
\text { Gastric, Breast, and } \\
\text { Ovarian Cancers }\end{array}$ & Interleukin-12 & $\begin{array}{c}\text { Genetic } \\
\text { Immunotherapy }\end{array}$ & Adenoviral Vector & $\begin{array}{l}\text { adenovirus-mediat } \\
\text { human } \\
\text { interleukin-12 }\end{array}$ & $\begin{array}{l}\text { Intratumoral } \\
\text { Injection }\end{array}$ & 1 & $\begin{array}{l}\text { Terminated No results } \\
\text { available }\end{array}$ & \\
\hline 32 & NCT00072098 & $\begin{array}{l}\text { Metastatic Liver } \\
\text { Tumors from } \\
\text { Colorectal, Pancreas, } \\
\text { Gastric, Breast, and } \\
\text { Ovarian Cancers }\end{array}$ & Interleukin-12 & $\begin{array}{c}\text { Genetic } \\
\text { Immunotherapy }\end{array}$ & Adenoviral Vector & $\begin{array}{c}\text { adenoviral } \\
\text { vector-delivered } \\
\text { interleukin-12 }\end{array}$ & $\begin{array}{l}\text { Intratumoral } \\
\text { Injection }\end{array}$ & 1 & $\begin{array}{l}\text { Terminated No results } \\
\text { available }\end{array}$ & \\
\hline 33 & NCT03198546 & $\mathrm{HCC}$ & GPC3 & $\begin{array}{l}\text { Tumor-related } \\
\text { Protein Coding }\end{array}$ & CAR-T cells & $\begin{array}{l}\text { GPC3 targeting } \\
\text { CAR-T cells }\end{array}$ & $\begin{array}{c}\text { Systemic or } \\
\text { local injections }\end{array}$ & 1 & $\begin{array}{c}\text { Recruiting No results } \\
\text { available Estimated } \\
\text { Completion Date: Aug, } \\
2022 \\
\end{array}$ & [87] \\
\hline 34 & NCT00103142 & $\begin{array}{l}\text { Metastatic Liver } \\
\text { Tumors from } \\
\text { Colorectal, Pancreas, } \\
\text { Gastric, Breast, and } \\
\text { Ovarian Cancers }\end{array}$ & $\begin{array}{c}\text { Vaccinia-Carcinoembryonic } \\
\text { antigen (CEA)-mucin } 1 \\
\text { (MUC-1)- Triad of } \\
\text { costimulatory molecules } \\
\text { TRICOM vaccine } \\
\text { (PANVAC-V) }\end{array}$ & $\begin{array}{l}\text { Tumor-related } \\
\text { Protein Coding }\end{array}$ & $\begin{array}{l}\text { Autologous dendritic } \\
\text { cells }\end{array}$ & Vaccination & & 2 & $\begin{array}{l}\text { Completed Results } \\
\text { available }\end{array}$ & [95] \\
\hline
\end{tabular}

HCC, hepatocellular carcinoma; CCC, cholangiocellular carcinoma; TACE, transarterial chemoembolization; TAE, transarterial embolization; HSVtk, thymidine kinase of herpes simplex virus; NY-ESO-1, New York esophageal squamous cell carcinoma 1; GPC-3, Glypican-3; LT, liver transplantation. 
Table 3. Summary of ongoing clinical trials for gene-based diagnosis.

\begin{tabular}{|c|c|c|c|c|c|c|c|c|}
\hline No & NCT Number & Official Title & Brief Summary & $\begin{array}{l}\text { Types of Liver } \\
\text { Tumors }\end{array}$ & Phase & Enrollment & $\begin{array}{l}\text { Current Status } \\
\text { and Results }\end{array}$ & Ref. \\
\hline 1 & NCT00373737 & $\begin{array}{l}\text { Microarray Analysis of Gene } \\
\text { Expression in Liver Tumors }\end{array}$ & $\begin{array}{l}\text { This study aims to study the gene expression profiles } \\
\text { of liver tumors to help us understand their biology, } \\
\text { and to find new tumor and treatment markers for } \\
\text { liver cancer. }\end{array}$ & Liver Cancer & Not Applicable & 300 & $\begin{array}{l}\text { Completed No } \\
\text { results reported } \\
\text { to date }\end{array}$ & \\
\hline 2 & NCT01786980 & $\begin{array}{l}\text { The Methylation Phenotype } \\
\text { Screening and Determination } \\
\text { Mode Study of Liver Cancer } \\
\text { Prognosis Related Gene }\end{array}$ & $\begin{array}{l}\text { This study aimed to obtain the important factors } \\
\text { affecting liver cancer prognosis, survival, recurrence } \\
\text { and metastasis in order to be able to find and } \\
\text { establish the effective prognostic evaluation method } \\
\text { by analyzing clinical information combining the } \\
\text { information of gene chip, methylation chip and flow } \\
\text { cytometry to carry out comprehensive researches on } \\
\text { liver cancer cell genetics, epigenetics, stem cells and } \\
\text { tumor microenvironment changes. }\end{array}$ & $\mathrm{HCC}$ & Not Applicable & 300 & $\begin{array}{l}\text { Completed No } \\
\text { results reported } \\
\text { to date }\end{array}$ & \\
\hline 3 & NCT00160940 & $\begin{array}{l}\text { Differential Gene Expression } \\
\text { in Liver Tissue and Blood } \\
\text { From Individuals With } \\
\text { Chronic Viral Hepatitis With } \\
\text { or Without a Complicating } \\
\text { Hepatoma or Autoimmune } \\
\text { Liver Disease }\end{array}$ & $\begin{array}{l}\text { This study aimed to find the genes that are expressed } \\
\text { in both the circulating white blood cells and the liver } \\
\text { of patients, using differential gene expression } \\
\text { analysis, with varying degrees of liver damage of } \\
\text { different causes with or without liver cancers. }\end{array}$ & $\begin{array}{l}\text { Primary Liver } \\
\text { Cancers } \\
\text { Metastatic Liver } \\
\text { Tumors }\end{array}$ & Not Applicable & 200 & $\begin{array}{l}\text { Recruiting No } \\
\text { results available }\end{array}$ & \\
\hline 4 & NCT01643499 & $\begin{array}{l}\text { A Genotype-guided Dosing } \\
\text { Study of mFOLFIRINOX in } \\
\text { Previously Untreated } \\
\text { Patients With Advanced } \\
\text { Gastrointestinal } \\
\text { Malignancies }\end{array}$ & $\begin{array}{l}\text { This study aimed to determine the dose of a } \\
\text { chemotherapy drug (irinotecan) in } 1 \text { st cycle in each of } \\
\text { two UGT1A1 genotype groups }\left({ }^{*} 11^{*} 1{ }^{*} 1^{*} 28\right) \text { using } \\
\text { genotype-guided dosing, that can be tolerated as part } \\
\text { of a combination of drugs. }\end{array}$ & $\begin{array}{l}\text { HCC CCC } \\
\text { Metastatic Liver } \\
\text { Tumors }\end{array}$ & 1 & 79 & $\begin{array}{l}\text { Active, not } \\
\text { recruiting } \\
\text { Estimated } \\
\text { Completion } \\
\text { Date: Apr, } 2019\end{array}$ & \\
\hline 5 & NCT02465060 & $\begin{array}{l}\text { Molecular Analysis for } \\
\text { Therapy Choice (MATCH) }\end{array}$ & $\begin{array}{l}\text { This phase II MATCH trial aimed to study how well } \\
\text { treatment that is directed by genetic testing works in } \\
\text { patients with solid tumors or lymphomas that have } \\
\text { progressed following at least one line of standard } \\
\text { treatment or for which no agreed upon treatment } \\
\text { approach exists. }\end{array}$ & $\begin{array}{l}\text { Primary Liver } \\
\text { Cancers } \\
\text { Metastatic Liver } \\
\text { Tumors }\end{array}$ & 2 & 6452 & $\begin{array}{l}\text { Recruiting No } \\
\text { results available } \\
\text { Estimated } \\
\text { Primary } \\
\text { Completion } \\
\text { Date: June, } 2022\end{array}$ & \\
\hline
\end{tabular}


Table 3. Cont.

\begin{tabular}{|c|c|c|c|c|c|c|c|c|}
\hline No & NCT Number & Official Title & Brief Summary & $\begin{array}{c}\text { Types of Liver } \\
\text { Tumors }\end{array}$ & Phase & Enrollment & $\begin{array}{c}\text { Current Status } \\
\text { and Results }\end{array}$ & Ref. \\
\hline 6 & NCT02733809 & $\begin{array}{l}\text { Mechanism of Sorafenib } \\
\text { Resistance in Patients With } \\
\text { Advanced Hepatocellular } \\
\text { Carcinoma }\end{array}$ & $\begin{array}{l}\text { This study aimed to clarify the hypothesis that } \\
\text { resistant tumor may be due to genetic mutations } \\
\text { and/or other alternative pathways that could be the } \\
\text { reason to overcome the SOR and still proliferate by } \\
\text { analyzing the gene expression profiling signature (a } \\
\text { set of dysregulated genes) for molecular classification, } \\
\text { diagnosis, and prognosis of several types of cancers. }\end{array}$ & $\mathrm{HCC}$ & 4 & 40 & $\begin{array}{l}\text { Recruiting No } \\
\text { results available } \\
\text { Estimated } \\
\text { Completion } \\
\text { Date: Dec, } 2024\end{array}$ & {$[169]$} \\
\hline 7 & NCT01752920 & $\begin{array}{l}\text { A Phase } 1 / 2 \text { Study of ARQ } \\
087 \text { in Adult Subjects With } \\
\text { Advanced Solid Tumors With } \\
\text { FGFR Genetic Alterations, } \\
\text { Including Intrahepatic } \\
\text { Cholangiocarcinoma With } \\
\text { FGFR2 Gene Fusion }\end{array}$ & $\begin{array}{l}\text { This open-label, Phase } 1 / 2 \text {, dose escalation and signal } \\
\text { finding study aimed to clarify the effect of } \\
\text { Derazantinib (ARQ 087), multi-kinase inhibitor } \\
\text { designed to preferentially inhibit the FGFR family of } \\
\text { kinases, in the cases with cholangiocarcinoma with } \\
\text { FGFR2 gene alterations. }\end{array}$ & $\mathrm{CCC}$ & $1 / 2$ & 119 & $\begin{array}{l}\text { Completed } \\
\text { Results partly } \\
\text { reported }\end{array}$ & {$[170]$} \\
\hline 8 & NCT03993873 & $\begin{array}{l}\text { A Phase 1, Open-Label, } \\
\text { Multi-Center, } \\
\text { First-in-Human Study of the } \\
\text { Safety, Tolerability, } \\
\text { Pharmacokinetics, and } \\
\text { Anti-Tumor Activity of } \\
\text { TPX-0022, a Novel } \\
\text { MET/CSF1R/SRC Inhibitor, in } \\
\text { Patients With Advanced } \\
\text { Solid Tumors Harboring } \\
\text { Genetic Alterations in MET }\end{array}$ & $\begin{array}{l}\text { A phase 1, first-in-human, open-label study to } \\
\text { determine the safety, tolerability, PK, and preliminary } \\
\text { efficacy of the novel MET/CSF1R/SRC inhibitor } \\
\text { TPX-0022 in adult subjects with advanced solid } \\
\text { tumors harboring genetic alterations in MET. The } \\
\text { study will proceed in three parts: a dose-escalation, a } \\
\text { food effect, and dose-expansion. }\end{array}$ & $\begin{array}{l}\text { Advanced Solid } \\
\text { Tumor } \\
\text { Metastatic Solid } \\
\text { Tumors }\end{array}$ & 1 & 120 & $\begin{array}{l}\text { Recruiting No } \\
\text { results available } \\
\text { Estimated } \\
\text { Completion } \\
\text { Date: Nov, } 2023\end{array}$ & \\
\hline 9 & NCT01892072 & $\begin{array}{l}\text { VEGF Signaling Promotes } \\
\text { Cell Growth and Metastasis } \\
\text { in Hepatocellular Carcinoma } \\
\text { in a VEGF Receptor } \\
\text { Mediated Pathway }\end{array}$ & $\begin{array}{l}\text { This study aimed to examine the VEGF signaling in } \\
\text { HCC cell lines and its mechanism in HCC growth, } \\
\text { proliferation and apoptosis. }\end{array}$ & $\mathrm{HCC}$ & Not Applicable & 50 & $\begin{array}{l}\text { Active, not } \\
\text { recruiting }\end{array}$ & \\
\hline 10 & NCT02507882 & $\begin{array}{l}\text { Impact of IL-28B rs12979860 } \\
\text { and rs4803217 Gene } \\
\text { Polymorphisms Associated } \\
\text { With miRNAs Deregulation } \\
\text { on HCV-related } \\
\text { Hepatocellular Carcinoma }\end{array}$ & $\begin{array}{l}\text { This study aimed to determine through investigating } \\
\text { a cohort of } 405 \text { patients, whether IL28B rs } 12979860 \\
\text { and rs } 4803217 \text { polymorphisms are associated to the } \\
\text { risk of HCC in chronic hepatitis C patients. }\end{array}$ & $\mathrm{HCC}$ & Not Applicable & 405 & $\begin{array}{l}\text { Not yet } \\
\text { recruiting }\end{array}$ & \\
\hline
\end{tabular}


Table 3. Cont.

\begin{tabular}{|c|c|c|c|c|c|c|c|c|}
\hline No & NCT Number & Official Title & Brief Summary & $\begin{array}{c}\text { Types of Liver } \\
\text { Tumors }\end{array}$ & Phase & Enrollment & $\begin{array}{l}\text { Current Status } \\
\text { and Results }\end{array}$ & Ref. \\
\hline 11 & NCT00858000 & $\begin{array}{l}\text { Analysis of the Incidence of } \\
\text { Expression of a Specific Set of } \\
\text { Genes and of Tumor } \\
\text { Antigens in Cancer Tissue } \\
\text { From Patients With } \\
\text { Hepatocellular Carcinoma }\end{array}$ & $\begin{array}{l}\text { This study aimed to analyze the expression of specific } \\
\text { markers in HCC and tumor-related antigens to } \\
\text { develop new approaches to treat this type of cancer } \\
\text { with genetic immunotherapy. }\end{array}$ & $\mathrm{HCC}$ & Not Applicable & 30 & $\begin{array}{l}\text { Completed No } \\
\text { results reported } \\
\text { to date }\end{array}$ & \\
\hline 12 & NCT03722628 & $\begin{array}{l}\text { The Assessment of Matrix } \\
\text { Metalloproteinase-1 } \\
\text { Genotypes Polymorphism as } \\
\text { a Risk Factor for } \\
\text { Hepatocellular Carcinoma in } \\
\text { Chronic Hepatitis C Patients } \\
\text { With Liver Cirrhosis }\end{array}$ & $\begin{array}{l}\text { This study aimed to assess whether the Matrix } \\
\text { Metalloproteinase-1 genotypes polymorphism can be } \\
\text { a risk factor for HCC in chronic hepatitis C patients } \\
\text { with liver cirrhosis. }\end{array}$ & $\mathrm{HCC}$ & Not Applicable & 200 & $\begin{array}{l}\text { Not yet } \\
\text { recruiting }\end{array}$ & [172] \\
\hline 13 & NCT01930383 & $\begin{array}{l}\text { Circulating Tumor Cells as } \\
\text { Biomarkers of Prognosis and } \\
\text { Predictors of Efficacy of Drug } \\
\text { Therapy for Patients With } \\
\text { Hepatocellular Carcinoma }\end{array}$ & $\begin{array}{l}\text { This study aimed to explore the clinical value of } \\
\text { correlation between circulating tumor cells numbers } \\
\text { and other clinical characteristics in HCC patients } \\
\text { with different stages. }\end{array}$ & $\mathrm{HCC}$ & Not Applicable & 150 & $\begin{array}{l}\text { Recruiting No } \\
\text { results available }\end{array}$ & \\
\hline 14 & NCT00619541 & $\begin{array}{l}\text { Phase II Study of Sorafenib } \\
\text { (Bay 43-9006) and Infusional } \\
\text { 5-Fluorouracil in Advanced } \\
\text { Hepatocellular Carcinoma. }\end{array}$ & $\begin{array}{l}\text { The purpose of this study is to use SOR + 5-FU to } \\
\text { evaluate activity, efficacy, safety, pharmacodynamics } \\
\text { and pharmacokinetics in patients with advanced } \\
\text { HCC. }\end{array}$ & $\mathrm{HCC}$ & 2 & 46 & $\begin{array}{l}\text { Completed } \\
\text { Results partly } \\
\text { reported }\end{array}$ & [173] \\
\hline
\end{tabular}

HCC, hepatocellular carcinoma; FOLFIRINOX regimen A regimen consisting of leucovorin calcium, fluorouracil, irinotecan hydrochloride, and oxaliplatin; SOR, sorafenib; FGFR, fibroblast growth factor receptor; CCC, cholangiocellular carcinoma. 
These studies include a microarray analysis of gene expression patterns in liver tumors to determine new tumor and treatment markers (NCT00373737); screening of the methylation phenotype of liver cancer to predict the prognosis (NCT01786980); analysis of different gene expression patterns in liver cancer and the blood to determine genes that are expressed in both circulating white blood cells and the liver of patients with varying degrees of liver damage of different causes (NCT00160940); a genotype-guided dosing analysis of mFOLFIRINOX for primary and metastatic liver cancers (NCT01643499); phase II molecular analysis to assess how well the treatment, directed by genetic testing, works in patients with solid tumors or lymphomas that have progressed following at least one line of standard treatment, or for which no agreed treatment approach exists (NCT02465060); an analysis of the molecular mechanism of sorafenib resistance in HCC patients assessed by gene expression profiles (NCT02733809) [169]; a phase I/II study to determine fibroblast growth factor receptor (FGFR) genetic alterations treated with novel FGFR inhibitor (ARQ-087) (NCT01752920) [170]; a phase I study to determine genetic alteration of the proto-oncogene MET in patients with solid tumors, including liver cancer treated with a novel MET/CSF1R/SRC inhibitor, TPX-0022 (NCT03993873); an investigation of vascular endothelial growth factor receptor (VEGFR), promoting cell growth and metastasis in HCC (NCT01892072); an assessment the impact of IL-28B rs12979860 and rs4803217 gene polymorphisms on hepatitis C virus (HCV)-related HCC (NCT02507882) [171]; analyses of the expression of a specific set of genes and of tumor antigens in cancer tissue from patients with HCC (NCT00858000); an assessment of matrix metalloproteinase-1 genotype polymorphism as a risk factor for HCV-related HCC (NCT03722628) [172]; determination of the role of circulating tumor cells as biomarkers of prognosis and predictors of efficacy of drug therapy for patients with HCC (NCT01930383); and a phase II study comparing the efficacy and safety of SOR versus infusional 5-fluorouracil (5-FU) in HCC based on the information of pERK concentration, phospho VEGFR concentration, plasma proteomics, and gene expression (NCT00619541) [173] (Table 3). While the detailed information is available for 14 studies, only a few results have been reported to date and the remainder of the study is mostly under assessment (Table 3). NCT01752920 showed the results of anti-tumor effect and safety of Derazantinib (ARQ 087) for unresectable intrahepatic cholangiocarcinomas with FGFR genetic alterations [170]. In addition, the phase 2 trial of the combination of SOR with 5-FU showed an encouraging disease control rate and overall survival [173]. Although NCT02733809 has a background of basic studies suggesting the molecular pathways blocked by the sorafenib [169], and NCT03722628 has evidence that the genetic variations of $M M P-11$ gene is related to the progression of HCC and can be a biomarker [172], no clinical results have been reported to date for these trials. Further studies are necessary to analyze gene expression related to chemosensitivity and toxicity, and to develop a standard and safe chemotherapy for HCC.

\section{Recent Progress}

CAR-T cells have been developed, and based on the success of treating hematological malignancies, they have become one of the most promising therapeutic options, even in solid tumors [174-176]. However, the lack of specific antigens in the solid tumors, especially liver cancer with heterogeneous tumor cells, limited penetration of the CAR-T-cells into tumor sites, and immunosuppressive tumor microenvironment are major obstacles to apply this method for HCC treatment. Most CARs use a single-chain variable fragment constructed from the variable heavy and light chains of a tumor-associated antigen-specific monoclonal antibody as the extracellular antigen recognition domain; a ligand or receptor can also be used. T-cells are collected from the patient and activated using anti-CD3 and IL-2, genetically modified, and expanded in vitro. The developed cells are then evaluated to ensure CAR expression, and infused to the patients. Currently, glypican-3 (GPC-3) has been tested to modify CAR-T-cells to treat HCC (NCT02715362, NCT03198546, and NCT02905188), as described [87], as well as for colorectal cancers (NCT02416466, NCT02850536, and NCT00004178). Similarly, T-cell-based ex vivo gene therapy has been tested (NCT01373047, NCT02932956, and NCT02869217). 
Genome-editing technologies, including ZFN, TALEN, and Cas9 systems, have significantly broadened the ability to edit the genomic DNA in vitro, and even in vivo [29,32,177,178]. Delivery of in vitro-transcribed mRNA-mediated delivery of nucleases has various applications and future prospects of genome editing in research and clinical trials [179]. Recent progress showed the significance of combining these viral and non-viral gene delivery approaches for therapeutic genome editing. For example, it has been reported that the lipid nanoparticle-mediated delivery of Cas 9 mRNA with AAVs encoding a sgRNA and a repair template to induce repair of a disease gene in adult animals showed successful genome editing and therapeutic effect [32]. Further efforts are necessary to develop the safe and effective delivery of the CRISPR/Cas9 system [180].

\section{Conclusions}

Among the various diseases affecting liver function, liver cancer is one of the leading causes of cancer-related deaths worldwide. Although conventional therapeutic options of surgery, ablation, chemoembolization, systemic chemotherapy, and molecularly targeted agents are partly effective for HCC, they are not sufficient for advanced-stage liver cancer in terms of efficacy. Therefore, the novel therapeutic option is an unmet need because of the heterogeneity of the tumors. On the basis of the development of genetic information, molecular biology, and analysis methodologies, gene therapy has shown promising anti-tumor effects in basic research and recent clinical trials. To further extend the applicability of gene therapy and the basic research in the field, we have carefully reviewed the genes and delivery methods, and summarized the currently ongoing clinical trials as of October 2019. Although further studies are essential to improve the efficacy and safety, with recent advances in promising technologies, such as gene editing by CRISPR/Cas9, CAR-T therapy, and the development of delivery systems armed with personal genomic information, gene therapy for liver cancer could improve the prognosis of patients with liver cancer.

Supplementary Materials: The following are available online at http://www.mdpi.com/2072-6694/11/12/1865/s1, Table S1 Full summary of ongoing clinical trials for gene therapy for liver cancers.

Author Contributions: K.K., T.Y., H.A., and S.T. collected, reviewed, and summarized data and prepared the manuscript.

Funding: This research and APC was funded by Grant-in-Aid for Scientific Research from the Japanese Society for the Promotion of Sciences 22890064, 23790595, 26860354, and 17K09408 to Kamimura K; 16K19333 to Yokoo T; and Takara Bio Award from JSGT to Kamimura K.

Conflicts of Interest: The authors declare that they have no conflict of interest.

\section{References}

1. Dooley, J.S.; Lok, A.S.; Garcia-Tsao, G.; Pinzani, M. Sherlock's Diseases of the Liver and Biliary System, 13th ed.; Wiley-Blackwell Science: Hoboken, NJ, USA, 2018.

2. Bray, F.; Ferlay, J.; Soerjomataram, I.; Siegel, R.L.; Torre, L.A.; Jemal, A. Global cancer statistics 2018: GLOBOCAN estimates of incidence and mortality worldwide for 36 cancers in 185 countries. CA Cancer J. Clin. 2018, 68, 394-424. [CrossRef] [PubMed]

3. Yang, J.D.; Hainaut, P.; Gores, G.J.; Amadou, A.; Plymoth, A.; Roberts, L.R. A global view of hepatocellular carcinoma: Trends, risk, prevention and management. Nat. Rev. Gastroenterol. Hepatol. 2019, 16, 589-604. [CrossRef] [PubMed]

4. Ogunwobi, O.O.; Harricharran, T.; Huaman, J.; Galuza, A.; Odumuwagun, O.; Tan, Y.; Ma, G.X.; Nguyen, M.T. Mechanisms of hepatocellular carcinoma progression. World J. Gastroenterol. 2019, 25, 2279-2293. [CrossRef] [PubMed]

5. Kanda, T.; Goto, T.; Hirotsu, Y.; Moriyama, M.; Omata, M. Molecular Mechanisms Driving Progression of Liver Cirrhosis towards Hepatocellular Carcinoma in Chronic Hepatitis B and C Infections: A Review. Int. J. Mol. Sci. 2019, 20, 1358. [CrossRef]

6. Ananthakrishnan, A.; Gogineni, V.; Saeian, K. Epidemiology of primary and secondary liver cancers. Semin. Intervent. Radiol. 2006, 23, 47-63. [CrossRef] 
7. Bruix, J.; Reig, M.; Sherman, M. Evidence-Based Diagnosis, Staging, and Treatment of Patients with Hepatocellular Carcinoma. Gastroenterology 2016, 150, 835-853. [CrossRef]

8. Llovet, J.M.; Zucman-Rossi, J.; Pikarsky, E.; Sangro, B.; Schwartz, M.; Sherman, M.; Gores, G. Hepatocellular carcinoma. Nat. Rev. Dis. Primers 2016, 2, 16018. [CrossRef]

9. EASL Clinical Practice Guidelines: Management of hepatocellular carcinoma. J. Hepatol. 2018, 69, $182-236$. [CrossRef]

10. Calderaro, J.; Ziol, M.; Paradis, V.; Zucman-Rossi, J. Molecular and histological correlations in liver cancer. J. Hepatol. 2019, 71, 616-630. [CrossRef]

11. Elnaggar, M.H.; Abushouk, A.I.; Lamloum, H.M.; Benmelouka, A.; Moatamed, S.A.; Abd-Elmegeed, H.; Attia, S.; Samir, A.; Amr, N.; Johar, D.; et al. Nanomedicine As A Putative Approach For Active Targeting of Hepatocellular Carcinoma. In Seminars in Cancer Biology; Academic Press: Cambridge, MA, USA, 2019.

12. Llovet, J.M.; Montal, R.; Villanueva, A. Randomized trials and endpoints in advanced HCC: Role of PFS as a surrogate of survival. J. Hepatol. 2019, 70, 1262-1277. [CrossRef]

13. Raja, A.; Park, I.; Haq, F.; Ahn, S.M. FGF19-FGFR4 Signaling in Hepatocellular Carcinoma. Cells 2019, 8, 536. [CrossRef] [PubMed]

14. El Dika, I.; Khalil, D.N.; Abou-Alfa, G.K. Immune checkpoint inhibitors for hepatocellular carcinoma. Cancer 2019, 125, 3312-3319. [CrossRef] [PubMed]

15. Fu, Y.; Liu, S.; Zeng, S.; Shen, H. From bench to bed: The tumor immune microenvironment and current immunotherapeutic strategies for hepatocellular carcinoma. J. Exp. Clin. Cancer Res. 2019, 38, 396. [CrossRef] [PubMed]

16. Lu, C.; Rong, D.; Zhang, B.; Zheng, W.; Wang, X.; Chen, Z.; Tang, W. Current perspectives on the immunosuppressive tumor microenvironment in hepatocellular carcinoma: Challenges and opportunities. Mol. Cancer 2019, 18, 130. [CrossRef]

17. Hou, J.; Zhang, H.; Sun, B.; Karin, M. The Immunobiology of Hepatocellular Carcinoma in Humans and Mice: Basic Concepts and Therapeutic Implications. J. Hepatol. 2019. [CrossRef]

18. Alaei-Mahabadi, B.; Bhadury, J.; Karlsson, J.W.; Nilsson, J.A.; Larsson, E. Global analysis of somatic structural genomic alterations and their impact on gene expression in diverse human cancers. Proc. Natl. Acad. Sci. USA 2016, 113, 13768-13773. [CrossRef]

19. Fujimoto, A.; Furuta, M.; Totoki, Y.; Tsunoda, T.; Kato, M.; Shiraishi, Y.; Tanaka, H.; Taniguchi, H.; Kawakami, Y.; Ueno, M.; et al. Whole-genome mutational landscape and characterization of noncoding and structural mutations in liver cancer. Nat. Genet. 2016, 48, 500-509. [CrossRef]

20. Rao, C.V.; Asch, A.S.; Yamada, H.Y. Frequently mutated genes/pathways and genomic instability as prevention targets in liver cancer. Carcinogenesis 2017, 38, 2-11. [CrossRef]

21. Gillet, J.P.; Andersen, J.B.; Madigan, J.P.; Varma, S.; Bagni, R.K.; Powell, K.; Burgan, W.E.; Wu, C.P.; Calcagno, A.M.; Ambudkar, S.V.; et al. A Gene Expression Signature Associated with Overall Survival in Patients with Hepatocellular Carcinoma Suggests a New Treatment Strategy. Mol. Pharmacol. 2016, 89, 263-272. [CrossRef]

22. Sun, W.; Shi, Q.; Zhang, H.; Yang, K.; Ke, Y.; Wang, Y.; Qiao, L. Advances in the techniques and methodologies of cancer gene therapy. Discov. Med. 2019, 27, 45-55.

23. Wang, X.; Tai, Z.; Zhang, W.; Gao, S. Current status of gene therapy for hepatocellular carcinoma, with a focus on gene delivery approaches. Curr. Gene Ther. 2015, 15, 120-141. [CrossRef] [PubMed]

24. Reghupaty, S.C.; Sarkar, D. Current Status of Gene Therapy in Hepatocellular Carcinoma. Cancers (Basel) 2019, 11, 1265. [CrossRef] [PubMed]

25. Dunbar, C.E.; High, K.A.; Joung, J.K.; Kohn, D.B.; Ozawa, K.; Sadelain, M. Gene therapy comes of age. Science 2018, 359, eaan4672. [CrossRef] [PubMed]

26. Naldini, L. Gene therapy returns to centre stage. Nature 2015, 526, 351-360. [CrossRef]

27. High, K.A.; Roncarolo, M.G. Gene Therapy. N. Engl. J. Med. 2019, 381, 455-464. [CrossRef]

28. Ginn, S.L.; Amaya, A.K.; Alexander, I.E.; Edelstein, M.; Abedi, M.R. Gene therapy clinical trials worldwide to 2017: An update. J. Gene Med. 2018, 20, e3015. [CrossRef]

29. Karimian, A.; Azizian, K.; Parsian, H.; Rafieian, S.; Shafiei-Irannejad, V.; Kheyrollah, M.; Yousefi, M.; Majidinia, M.; Yousefi, B. CRISPR/Cas9 technology as a potent molecular tool for gene therapy. J. Cell. Physiol. 2019, 234, 12267-12277. [CrossRef] 
30. Chew, W.L.; Tabebordbar, M.; Cheng, J.K.; Mali, P.; Wu, E.Y.; Ng, A.H.; Zhu, K.; Wagers, A.J.; Church, G.M. A multifunctional AAV-CRISPR-Cas9 and its host response. Nat. Methods 2016, 13, 868-874. [CrossRef]

31. Alsaggara, M.; Liu, D. Liver-Targeted Gene and Cell Therapies: An Overview. In Gene Therapy and Cell Therapy through the Liver; Terai, S., Suda, T., Eds.; Springer: Tokyo, Japan, 2016.

32. Yin, H.; Song, C.Q.; Dorkin, J.R.; Zhu, L.J.; Li, Y.; Wu, Q.; Park, A.; Yang, J.; Suresh, S.; Bizhanova, A.; et al. Therapeutic genome editing by combined viral and non-viral delivery of CRISPR system components in vivo. Nat. Biotechnol. 2016, 34, 328-333. [CrossRef]

33. Meng, X.; Franklin, D.A.; Dong, J.; Zhang, Y. MDM2-p53 pathway in hepatocellular carcinoma. Cancer Res. 2014, 74, 7161-7167. [CrossRef]

34. Erstad, D.J.; Fuchs, B.C.; Tanabe, K.K. Molecular signatures in hepatocellular carcinoma: A step toward rationally designed cancer therapy. Cancer 2018, 124, 3084-3104. [CrossRef] [PubMed]

35. Anestopoulos, I.; Voulgaridou, G.P.; Georgakilas, A.G.; Franco, R.; Pappa, A.; Panayiotidis, M.I. Epigenetic therapy as a novel approach in hepatocellular carcinoma. Pharmacol. Ther. 2015, 145, 103-119. [CrossRef] [PubMed]

36. Quetglas, I.M.; Moeini, A.; Pinyol, R.; Llovet, J.M. Integration of genomic information in the clinical management of HCC. Best Pract. Res. Clin. Gastroenterol. 2014, 28, 831-842. [CrossRef] [PubMed]

37. Scaggiante, B.; Kazemi, M.; Pozzato, G.; Dapas, B.; Farra, R.; Grassi, M.; Zanconati, F.; Grassi, G. Novel hepatocellular carcinoma molecules with prognostic and therapeutic potentials. World J. Gastroenterol. 2014, 20, 1268-1288. [CrossRef]

38. Berasain, C.; Avila, M.A. The EGFR signalling system in the liver: From hepatoprotection to hepatocarcinogenesis. J. Gastroenterol. 2014, 49, 9-23. [CrossRef]

39. Xiao, H.; Tong, R.; Ding, C.; Lv, Z.; Du, C.; Peng, C.; Cheng, S.; Xie, H.; Zhou, L.; Wu, J.; et al. Gamma-H2AX promotes hepatocellular carcinoma angiogenesis via EGFR/HIF-1alpha/VEGF pathways under hypoxic condition. Oncotarget 2015, 6, 2180-2192. [CrossRef]

40. Wen, Y.; Zhou, X.; Lu, M.; He, M.; Tian, Y.; Liu, L.; Wang, M.; Tan, W.; Deng, Y.; Yang, X.; et al. Bclaf1 promotes angiogenesis by regulating HIF-1alpha transcription in hepatocellular carcinoma. Oncogene 2019, 38, 1845-1859. [CrossRef]

41. Ni, J.Y.; Xu, L.F.; Wang, W.D.; Huang, Q.S.; Sun, H.L.; Chen, Y.T. Transarterial embolization combined with RNA interference targeting hypoxia-inducible factor-1alpha for hepatocellular carcinoma: A preliminary study of rat model. J. Cancer Res. Clin. Oncol. 2017, 143, 199-207. [CrossRef]

42. Gu, D.L.; Chen, Y.H.; Shih, J.H.; Lin, C.H.; Jou, Y.S.; Chen, C.F. Target genes discovery through copy number alteration analysis in human hepatocellular carcinoma. World J. Gastroenterol. 2013, 19, 8873-8879. [CrossRef]

43. Cornella, H.; Alsinet, C.; Sayols, S.; Zhang, Z.; Hao, K.; Cabellos, L.; Hoshida, Y.; Villanueva, A.; Thung, S.; Ward, S.C.; et al. Unique genomic profile of fibrolamellar hepatocellular carcinoma. Gastroenterology 2015, 148, 806-818. [CrossRef]

44. Munoz-Garrido, P.; Andersen, J.B. Genetic Optimization of Liver Cancer Therapy: A Patient-Derived Primary Cancer Cell-Based Model. Gastroenterology 2017, 152, 19-21. [CrossRef] [PubMed]

45. Gao, Q.; Wang, Z.C.; Duan, M.; Lin, Y.H.; Zhou, X.Y.; Worthley, D.L.; Wang, X.Y.; Niu, G.; Xia, Y.; Deng, M.; et al. Cell Culture System for Analysis of Genetic Heterogeneity Within Hepatocellular Carcinomas and Response to Pharmacologic Agents. Gastroenterology 2017, 152, 232-242. [CrossRef] [PubMed]

46. Cancer Genome Atlas Research Network. Electronic address: Wheeler@bcm.edu; Cancer Genome Atlas Research Network: Comprehensive and Integrative Genomic Characterization of Hepatocellular Carcinoma. Cell 2017, 169, 1327-1341. [CrossRef] [PubMed]

47. Shen, A.; Liu, S.; Yu, W.; Deng, H.; Li, Q. p53 gene therapy-based transarterial chemoembolization for unresectable hepatocellular carcinoma: A prospective cohort study. J. Gastroenterol. Hepatol. 2015, 30, 1651-1656. [CrossRef]

48. Chawla, S.P.; Bruckner, H.; Morse, M.A.; Assudani, N.; Hall, F.L.; Gordon, E.M. A Phase I-II Study Using Rexin-G Tumor-Targeted Retrovector Encoding a Dominant-Negative Cyclin G1 Inhibitor for Advanced Pancreatic Cancer. Mol. Ther. Oncolytics 2019, 12, 56-67. [CrossRef]

49. Santiago-Ortiz, J.L.; Schaffer, D.V. Adeno-associated virus (AAV) vectors in cancer gene therapy. J. Control. Release 2016, 240, 287-301. [CrossRef] 
50. Wang, Y.; Huang, F.; Cai, H.; Zhong, S.; Liu, X.; Tan, W.S. Potent antitumor effect of TRAIL mediated by a novel adeno-associated viral vector targeting to telomerase activity for human hepatocellular carcinoma. J. Gene Med. 2008, 10, 518-526. [CrossRef]

51. Ran, Z.; Chen, W.; Shang, J.; Li, X.; Nie, Z.; Yang, J.; Li, N. Clinicopathological and prognostic implications of polo-like kinase 1 expression in colorectal cancer: A systematic review and meta-analysis. Gene 2019, 721, 144097. [CrossRef]

52. Fu, Z.; Wen, D. The Emerging Role of Polo-Like Kinase 1 in Epithelial-Mesenchymal Transition and Tumor Metastasis. Cancers (Basel) 2017, 9, 131. [CrossRef]

53. Strebhardt, K.; Ullrich, A. Targeting polo-like kinase 1 for cancer therapy. Nat. Rev. Cancer 2006, 6, 321-330. [CrossRef]

54. Van Haele, M.; Moya, I.M.; Karaman, R.; Rens, G.; Snoeck, J.; Govaere, O.; Nevens, F.; Verslype, C.; Topal, B.; Monbaliu, D.; et al. YAP and TAZ Heterogeneity in Primary Liver Cancer: An Analysis of Its Prognostic and Diagnostic Role. Int. J. Mol. Sci. 2019, 20, 638. [CrossRef] [PubMed]

55. Feng, X.; Lu, T.; Li, J.; Yang, R.; Hu, L.; Ye, Y.; Mao, F.; He, L.; Xu, J.; Wang, Z.; et al. The novel tumor suppressor IRF2BP2 regulates Hippo pathway in liver cancer via a feedback loop. Hepatology 2019. [CrossRef] [PubMed]

56. Huang, Z.; Zhou, J.K.; Wang, K.; Chen, H.; Qin, S.; Liu, J.; Luo, M.; Chen, Y.; Jiang, J.; Zhou, L.; et al. PDLIM1 inhibits tumor metastasis through activating Hippo signaling in hepatocellular carcinoma. Hepatology 2019. [CrossRef] [PubMed]

57. Rafatmanesh, A.; Behjati, M.; Mobasseri, N.; Sarvizadeh, M.; Mazoochi, T.; Karimian, M. The survivin molecule as a double-edged sword in cellular physiologic and pathologic conditions and its role as a potential biomarker and therapeutic target in cancer. J. Cell. Physiol. 2019. [CrossRef]

58. Namgung, Y.; Kim, S.Y.; Kim, I. Down-regulation of Survivin by BIX-01294 Pretreatment Overcomes Resistance of Hepatocellular Carcinoma Cells to TRAIL. Anticancer Res. 2019, 39, 3571-3578. [CrossRef]

59. Sehgal, A.; Vaishnaw, A.; Fitzgerald, K. Liver as a target for oligonucleotide therapeutics. J. Hepatol. 2013, 59, 1354-1359. [CrossRef]

60. Berraondo, P.; Martini, P.G.V.; Avila, M.A.; Fontanellas, A. Messenger RNA therapy for rare genetic metabolic diseases. Gut 2019, 68, 1323-1330. [CrossRef]

61. Hajiasgharzadeh, K.; Somi, M.H.; Shanehbandi, D.; Mokhtarzadeh, A.; Baradaran, B. Small interfering RNA-mediated gene suppression as a therapeutic intervention in hepatocellular carcinoma. J. Cell. Physiol. 2019, 234, 3263-3276. [CrossRef]

62. Scarabel, L.; Perrone, F.; Garziera, M.; Farra, R.; Grassi, M.; Musiani, F.; Russo Spena, C.; Salis, B.; De Stefano, L.; Toffoli, G.; et al. Strategies to optimize siRNA delivery to hepatocellular carcinoma cells. Expert Opin. Drug Deliv. 2017, 14, 797-810. [CrossRef]

63. Bernstein, E.; Caudy, A.A.; Hammond, S.M.; Hannon, G.J. Role for a bidentate ribonuclease in the initiation step of RNA interference. Nature 2001, 409, 363-366. [CrossRef]

64. Nakao, K.; Miyaaki, H.; Ichikawa, T. Antitumor function of microRNA-122 against hepatocellular carcinoma. J. Gastroenterol. 2014, 49, 589-593. [CrossRef] [PubMed]

65. Lanzafame, M.; Bianco, G.; Terracciano, L.M.; Ng, C.K.Y.; Piscuoglio, S. The Role of Long Non-Coding RNAs in Hepatocarcinogenesis. Int. J. Mol. Sci. 2018, 19, 682. [CrossRef] [PubMed]

66. Qiu, L.; Tang, Q.; Li, G.; Chen, K. Long non-coding RNAs as biomarkers and therapeutic targets: Recent insights into hepatocellular carcinoma. Life Sci. 2017, 191, 273-282. [CrossRef] [PubMed]

67. Zhang, Z.; Wang, S.; Liu, Y.; Meng, Z.; Chen, F. Low lncRNA ZNF385DAS2 expression and its prognostic significance in liver cancer. Oncol. Rep. 2019, 42, 1110-1124. [PubMed]

68. Huang, J.L.; Zheng, L.; Hu, Y.W.; Wang, Q. Characteristics of long non-coding RNA and its relation to hepatocellular carcinoma. Carcinogenesis 2014, 35, 507-514. [CrossRef]

69. Li, C.; Xu, X. Biological functions and clinical applications of exosomal non-coding RNAs in hepatocellular carcinoma. Cell. Mol. Life Sci. 2019, 76, 4203-4219. [CrossRef]

70. Springer, A.D.; Dowdy, S.F. GalNAc-siRNA Conjugates: Leading the Way for Delivery of RNAi Therapeutics. Nucleic Acid Ther. 2018, 28, 109-118. [CrossRef]

71. Bartel, D.P. Metazoan MicroRNAs. Cell 2018, 173, 20-51. [CrossRef]

72. Duzgunes, N. Origins of Suicide Gene Therapy. Methods Mol. Biol. 2019, 1895, 1-9. 
73. Sangro, B.; Mazzolini, G.; Ruiz, M.; Ruiz, J.; Quiroga, J.; Herrero, I.; Qian, C.; Benito, A.; Larrache, J.; Olague, C.; et al. A phase I clinical trial of thymidine kinase-based gene therapy in advanced hepatocellular carcinoma. Cancer Gene Ther. 2010, 17, 837-843. [CrossRef]

74. Kemeny, N.; Brown, K.; Covey, A.; Kim, T.; Bhargava, A.; Brody, L.; Guilfoyle, B.; Haag, N.P.; Karrasch, M.; Glasschroeder, B.; et al. Phase I, open-label, dose-escalating study of a genetically engineered herpes simplex virus, NV1020, in subjects with metastatic colorectal carcinoma to the liver. Hum. Gene Ther. 2006, 17, 1214-1224. [CrossRef] [PubMed]

75. Wills, K.N.; Huang, W.M.; Harris, M.P.; Machemer, T.; Maneval, D.C.; Gregory, R.J. Gene therapy for hepatocellular carcinoma: Chemosensitivity conferred by adenovirus-mediated transfer of the HSV-1 thymidine kinase gene. Cancer Gene Ther. 1995, 2, 191-197. [PubMed]

76. Yamada, T.; Hamano, Y.; Hasegawa, N.; Seo, E.; Fukuda, K.; Yokoyama, K.K.; Hyodo, I.; Abei, M. Oncolytic Virotherapy and Gene Therapy Strategies for Hepatobiliary Cancers. Curr. Cancer Drug Targets 2018, 18, 188-201. [CrossRef] [PubMed]

77. Harrington, K.; Freeman, D.J.; Kelly, B.; Harper, J.; Soria, J.C. Optimizing oncolytic virotherapy in cancer treatment. Nat. Rev. Drug Discov. 2019, 18, 689-706. [CrossRef]

78. Lai, Y.H.; Lin, C.C.; Chen, S.H.; Tai, C.K. Tumor-specific suicide gene therapy for hepatocellular carcinoma by transcriptionally targeted retroviral replicating vectors. Gene Ther. 2015, 22, 155-162. [CrossRef] [PubMed]

79. Chen, Z.H.; Yu, Y.P.; Zuo, Z.H.; Nelson, J.B.; Michalopoulos, G.K.; Monga, S.; Liu, S.; Tseng, G.; Luo, J.H. Targeting genomic rearrangements in tumor cells through Cas9-mediated insertion of a suicide gene. Nat. Biotechnol. 2017, 35, 543-550. [CrossRef] [PubMed]

80. Lin, B.; Gao, A.; Zhang, R.; Ma, H.; Shen, H.; Hu, Q.; Zhang, H.; Zhao, M.; Lan, X.; Liu, K. Use of a Novel Integrase-Deficient Lentivirus for Targeted Anti-Cancer Therapy with Survivin Promoter-Driven Diphtheria Toxin A. Medicine 2015, 94, e1301. [CrossRef]

81. Hanna, N.; Ohana, P.; Konikoff, F.M.; Leichtmann, G.; Hubert, A.; Appelbaum, L.; Kopelman, Y.; Czerniak, A.; Hochberg, A. Phase 1/2a, dose-escalation, safety, pharmacokinetic and preliminary efficacy study of intratumoral administration of BC-819 in patients with unresectable pancreatic cancer. Cancer Gene Ther. 2012, 19, 374-381. [CrossRef]

82. Scaiewicz, V.; Sorin, V.; Fellig, Y.; Birman, T.; Mizrahi, A.; Galula, J.; Abu-Lail, R.; Shneider, T.; Ohana, P.; Buscail, L.; et al. Use of H19 Gene Regulatory Sequences in DNA-Based Therapy for Pancreatic Cancer. J. Oncol. 2010, 2010. [CrossRef]

83. Mizrahi, A.; Czerniak, A.; Levy, T.; Amiur, S.; Gallula, J.; Matouk, I.; Abu-lail, R.; Sorin, V.; Birman, T.; de Groot, N.; et al. Development of targeted therapy for ovarian cancer mediated by a plasmid expressing diphtheria toxin under the control of H19 regulatory sequences. J. Transl. Med. 2009, 7, 69. [CrossRef]

84. Amit, D.; Hochberg, A. Development of targeted therapy for a broad spectrum of cancers (pancreatic cancer, ovarian cancer, glioblastoma and HCC) mediated by a double promoter plasmid expressing diphtheria toxin under the control of H19 and IGF2-P4 regulatory sequences. Int. J. Clin. Exp. Med. 2012, 5, 296-305. [PubMed]

85. Sidi, A.A.; Ohana, P.; Benjamin, S.; Shalev, M.; Ransom, J.H.; Lamm, D.; Hochberg, A.; Leibovitch, I. Phase I/II marker lesion study of intravesical BC-819 DNA plasmid in H19 over expressing superficial bladder cancer refractory to bacillus Calmette-Guerin. J. Urol. 2008, 180, 2379-2383. [CrossRef] [PubMed]

86. Montalbano, M.; Georgiadis, J.; Masterson, A.L.; McGuire, J.T.; Prajapati, J.; Shirafkan, A.; Rastellini, C.; Cicalese, L. Biology and function of glypican-3 as a candidate for early cancerous transformation of hepatocytes in hepatocellular carcinoma (Review). Oncol. Rep. 2017, 37, 1291-1300. [CrossRef] [PubMed]

87. Jiang, Z.; Jiang, X.; Chen, S.; Lai, Y.; Wei, X.; Li, B.; Lin, S.; Wang, S.; Wu, Q.; Liang, Q.; et al. Anti-GPC3-CAR T Cells Suppress the Growth of Tumor Cells in Patient-Derived Xenografts of Hepatocellular Carcinoma. Front. Immunol. 2016, 7, 690. [CrossRef] [PubMed]

88. Flecken, T.; Schmidt, N.; Hild, S.; Gostick, E.; Drognitz, O.; Zeiser, R.; Schemmer, P.; Bruns, H.; Eiermann, T.; Price, D.A.; et al. Immunodominance and functional alterations of tumor-associated antigen-specific CD8+ T-cell responses in hepatocellular carcinoma. Hepatology 2014, 59, 1415-1426. [CrossRef] [PubMed]

89. Dauch, D.; Rudalska, R.; Cossa, G.; Nault, J.C.; Kang, T.W.; Wuestefeld, T.; Hohmeyer, A.; Imbeaud, S.; Yevsa, T.; Hoenicke, L.; et al. A MYC-aurora kinase A protein complex represents an actionable drug target in p53-altered liver cancer. Nat. Med. 2016, 22, 744-753. [CrossRef] 
90. Kanwal, F.; Singal, A.G. Surveillance for Hepatocellular Carcinoma: Current Best Practice and Future Direction. Gastroenterology 2019, 157, 54-64. [CrossRef]

91. Wong, R.J.; Ahmed, A.; Gish, R.G. Elevated alpha-fetoprotein: Differential diagnosis-Hepatocellular carcinoma and other disorders. Clin. Liver Dis. 2015, 19, 309-323. [CrossRef]

92. Butterfield, L.H.; Economou, J.S.; Gamblin, T.C.; Geller, D.A. Alpha fetoprotein DNA prime and adenovirus boost immunization of two hepatocellular cancer patients. J. Transl. Med. 2014, 12, 86. [CrossRef]

93. Bakalakos, E.A.; Burak, W.E., Jr.; Young, D.C.; Martin, E., Jr. Is carcino-embryonic antigen useful in the follow-up management of patients with colorectal liver metastases? Am. J. Surg. 1999, 177, 2-6. [CrossRef]

94. Rizeq, B.; Zakaria, Z.; Ouhtit, A. Towards understanding the mechanisms of actions of carcinoembryonic antigen-related cell adhesion molecule 6 in cancer progression. Cancer Sci. 2018, 109, 33-42. [CrossRef]

95. Morse, M.A.; Niedzwiecki, D.; Marshall, J.L.; Garrett, C.; Chang, D.Z.; Aklilu, M.; Crocenzi, T.S.; Cole, D.J.; Dessureault, S.; Hobeika, A.C.; et al. A randomized phase II study of immunization with dendritic cells modified with poxvectors encoding CEA and MUC1 compared with the same poxvectors plus GM-CSF for resected metastatic colorectal cancer. Ann. Surg. 2013, 258, 879-886. [CrossRef] [PubMed]

96. Loibl, S.; Gianni, L. HER2-positive breast cancer. Lancet 2017, 389, 2415-2429. [CrossRef]

97. Gordeeva, O. Cancer-testis antigens: Unique cancer stem cell biomarkers and targets for cancer therapy. Semin. Cancer Biol. 2018, 53, 75-89. [CrossRef]

98. Patel, S.V.; Khan, D.A. Adverse Reactions to Biologic Therapy. Immunol. Allergy Clin. 2017, 37, $397-412$. [CrossRef] [PubMed]

99. Duan, F.; Lam, M.G. Delivery approaches of gene therapy in hepatocellular carcinoma. AntiCancer Res. 2013, 33, 4711-4718. [PubMed]

100. Wang, Y.; Du, H.; Zhai, G. Recent advances in active hepatic targeting drug delivery system. Curr. Drug Targets 2014, 15, 573-599. [CrossRef]

101. Kamimura, K.; Suda, T.; Zhang, G.; Liu, D. Advances in gene delivery systems. Pharm. Med. 2011, 25, 293-306. [CrossRef]

102. Kamimura, K.; Liu, D. Physical approaches for nucleic acid delivery to liver. AAPS J. 2008, 10, 589-595. [CrossRef]

103. Kamimura, K.; Suda, T.; Kanefuji, T.; Yokoo, T.; Abe, H.; Kobayashi, Y.; Aoyagi, Y.; Liu, D. Image-Guided Hydrodynamic Gene Delivery to the Liver: Toward Clinical Applications. In Gene Therapy and Cell Therapy through the Liver; Terai, S., Suda, T., Eds.; Springer: Tokyo, Japan, 2016; Chapter 8.

104. Thomas, C.E.; Ehrhardt, A.; Kay, M.A. Progress and problems with the use of viral vectors for gene therapy. Nat. Rev. Genet. 2003, 4, 346-358. [CrossRef]

105. Rittie, L.; Athanasopoulos, T.; Calero-Garcia, M.; Davies, M.L.; Dow, D.J.; Howe, S.J.; Morrison, A.; Ricciardelli, I.; Saudemont, A.; Jespers, L.; et al. The Landscape of Early Clinical Gene Therapies outside of Oncology. Mol. Ther. 2019. [CrossRef] [PubMed]

106. van der Laan, L.J.; Wang, Y.; Tilanus, H.W.; Janssen, H.L.; Pan, Q. AAV-mediated gene therapy for liver diseases: The prime candidate for clinical application? Expert Opin. Biol. Ther. 2011, 11, 315-327. [CrossRef] [PubMed]

107. Dismuke, D.; Samulski, R.J. Hepatic gene therapy using lentiviral vectors: Has safety been established? Hepatology 2013, 58, 13-14. [CrossRef] [PubMed]

108. Vetrini, F.; Ng, P. Liver-directed gene therapy with helper-dependent adenoviral vectors: Current state of the art and future challenges. Curr. Pharm. Des. 2011, 17, 2488-2499. [CrossRef]

109. Sweeney, N.P.; Meng, J.; Patterson, H.; Morgan, J.E.; McClure, M. Delivery of large transgene cassettes by foamy virus vector. Sci. Rep. 2017, 7, 8085. [CrossRef]

110. Uchida, H.; Hamada, H.; Nakano, K.; Kwon, H.; Tahara, H.; Cohen, J.B.; Glorioso, J.C. Oncolytic Herpes Simplex Virus Vectors Fully Retargeted to Tumor- Associated Antigens. Curr. Cancer Drug Targets 2018, 18, 162-170. [CrossRef]

111. Liu, J.; Jaijyan, D.K.; Tang, Q.; Zhu, H. Promising Cytomegalovirus-Based Vaccine Vector Induces Robust CD8(+) T-Cell Response. Int. J. Mol. Sci. 2019, 20, 4457. [CrossRef]

112. Atchison, R.W.; Casto, B.C.; Hammon, W.M. Adenovirus-associated defective virus particles. Science 1965, 149, 754-756. [CrossRef] 
113. Wang, Y.G.; Huang, P.P.; Zhang, R.; Ma, B.Y.; Zhou, X.M.; Sun, Y.F. Targeting adeno-associated virus and adenoviral gene therapy for hepatocellular carcinoma. World J. Gastroenterol. 2016, 22, 326-337. [CrossRef] [PubMed]

114. Chandler, R.J.; Tarasenko, T.N.; Cusmano-Ozog, K.; Sun, Q.; Sutton, V.R.; Venditti, C.P.; McGuire, P.J. Liver-directed adeno-associated virus serotype 8 gene transfer rescues a lethal murine model of citrullinemia type 1. Gene Ther. 2013, 20, 1188. [CrossRef]

115. Nathwani, A.C.; Tuddenham, E.G.; Rangarajan, S.; Rosales, C.; McIntosh, J.; Linch, D.C.; Chowdary, P.; Riddell, A.; Pie, A.J.; Harrington, C.; et al. Adenovirus-Associated Virus Vector-Mediated Gene Transfer in Hemophilia, B. N. Engl. J. Med. 2011, 365, 2357-2365. [CrossRef] [PubMed]

116. Peyvandi, F.; Garagiola, I. Clinical advances in gene therapy updates on clinical trials of gene therapy in hemophilia. Haemophilia 2019, 25, 738-746. [CrossRef] [PubMed]

117. Li, H.; Lu, Y.; Witek, R.P.; Chang, L.J.; Campbell-Thompson, M.; Jorgensen, M.; Petersen, B.; Song, S. Ex vivo transduction and transplantation of bone marrow cells for liver gene delivery of alpha1-antitrypsin. Mol. Ther. 2010, 18, 1553-1558. [CrossRef]

118. Suhy, D.A.; Kao, S.C.; Mao, T.; Whiteley, L.; Denise, H.; Souberbielle, B.; Burdick, A.D.; Hayes, K.; Wright, J.F.; Lavender, H.; et al. Safe, long-term hepatic expression of anti-HCV shRNA in a nonhuman primate model. Mol. Ther. 2012, 20, 1737-1749. [CrossRef] [PubMed]

119. Su, H.; Chang, J.C.; Xu, S.M.; Kan, Y.W. Selective killing of AFP-positive hepatocellular carcinoma cells by adeno-associated virus transfer of the herpes simplex virus thymidine kinase gene. Hum. Gene Ther. 1996, 7, 463-470. [CrossRef] [PubMed]

120. Bell, P.; Gao, G.; Haskins, M.E.; Wang, L.; Sleeper, M.; Wang, H.; Calcedo, R.; Vandenberghe, L.H.; Chen, S.J.; Weisse, C.; et al. Evaluation of adeno-associated viral vectors for liver-directed gene transfer in dogs. Hum. Gene Ther. 2011, 22, 985-997. [CrossRef]

121. Brunetti-Pierri, N.; Liou, A.; Patel, P.; Palmer, D.; Grove, N.; Finegold, M.; Piccolo, P.; Donnachie, E.; Rice, K.; Beaudet, A.; et al. Balloon Catheter Delivery of Helper-dependent Adenoviral Vector Results in Sustained, Therapeutic hFIX Expression in Rhesus Macaques. Mol. Ther. 2012, 20, 1863-1870. [CrossRef]

122. Sobrevals, L.; Enguita, M.; Rodriguez, C.; Gonzalez-Rojas, J.; Alzaguren, P.; Razquin, N.; Prieto, J.; Fortes, P. AAV vectors transduce hepatocytes in vivo as efficiently in cirrhotic as in healthy rat livers. Gene Ther. 2012, 19, 411-417. [CrossRef]

123. Sabatino, D.E.; Lange, A.M.; Altynova, E.S.; Sarkar, R.; Zhou, S.; Merricks, E.P.; Franck, H.G.; Nichols, T.C.; Arruda, V.R.; Kazazian Jr, H. Efficacy and safety of long-term prophylaxis in severe hemophilia A dogs following liver gene therapy using AAV vectors. Mol. Ther. 2011, 19, 442-449. [CrossRef]

124. Penuelas, I.; Mazzolini, G.; Boan, J.F.; Sangro, B.; Marti-Climent, J.; Ruiz, M.; Ruiz, J.; Satyamurthy, N.; Qian, C.; Barrio, J.R.; et al. Positron emission tomography imaging of adenoviral-mediated transgene expression in liver cancer patients. Gastroenterology 2005, 128, 1787-1795. [CrossRef]

125. Wang, W.; Li, W.; Ma, N.; Steinhoff, G. Non-viral gene delivery methods. Curr. Pharm. Biotechnol. 2013, 14, 46-60. [PubMed]

126. Pal Singh, P.; Vithalapuram, V.; Metre, S.; Kodipyaka, R. Lipoplex-based therapeutics for effective oligonucleotide delivery: A compendious review. J. Liposome Res. 2019, 1-23. [CrossRef] [PubMed]

127. Cordeiro, R.A.; Serra, A.; Coelho, J.F.J.; Faneca, H. Poly (beta-amino ester)-based gene delivery systems: From discovery to therapeutic applications. J. Control. Release 2019, 310, 155-187. [CrossRef] [PubMed]

128. Bolhassani, A. Improvements in chemical carriers of proteins and peptides. Cell Biol. Int. 2019, 43, 437-452. [CrossRef] [PubMed]

129. Kulkarni, J.A.; Cullis, P.R.; van der Meel, R. Lipid Nanoparticles Enabling Gene Therapies: From Concepts to Clinical Utility. Nucleic. Acid Ther. 2018, 28, 146-157. [CrossRef]

130. Cullis, P.R.; Hope, M.J. Lipid Nanoparticle Systems for Enabling Gene Therapies. Mol. Ther. 2017, 25, 1467-1475. [CrossRef]

131. Varshosaz, J.; Farzan, M. Nanoparticles for targeted delivery of therapeutics and small interfering RNAs in hepatocellular carcinoma. World J. Gastroenterol. 2015, 21, 12022-12041. [CrossRef]

132. Hashida, M.; Nishikawa, M.; Yamashita, F.; Takakura, Y. Cell-specific delivery of genes with glycosylated carriers. Adv. Drug Deliv. Rev. 2001, 52, 187-196. [CrossRef] 
133. Adrian, J.E.; Poelstra, K.; Scherphof, G.L.; Meijer, D.K.; van Loenen-Weemaes, A.M.; Reker-Smit, C.; Morselt, H.W.; Zwiers, P.; Kamps, J.A. Effects of a new bioactive lipid-based drug carrier on cultured hepatic stellate cells and liver fibrosis in bile duct-ligated rats. J. Pharmacol. Exp. Ther. 2007, 321, 536-543. [CrossRef]

134. Puxbaum, V.; Nimmerfall, E.; Bauerl, C.; Taub, N.; Blaas, P.M.; Wieser, J.; Mikula, M.; Mikulits, W.; Ng, K.M.; Yeoh, G.C.; et al. M6P/IGF2R modulates the invasiveness of liver cells via its capacity to bind mannose 6-phosphate residues. J. Hepatol. 2012, 57, 337-343. [CrossRef]

135. Zakeri, A.; Kouhbanani, M.A.J.; Beheshtkhoo, N.; Beigi, V.; Mousavi, S.M.; Hashemi, S.A.R.; Karimi Zade, A.; Amani, A.M.; Savardashtaki, A.; Mirzaei, E.; et al. Polyethylenimine-based nanocarriers in co-delivery of drug and gene: A developing horizon. Nano Rev. Exp. 2018, 9, 1488497. [CrossRef] [PubMed]

136. Zamboni, C.G.; Kozielski, K.L.; Vaughan, H.J.; Nakata, M.M.; Kim, J.; Higgins, L.J.; Pomper, M.G.; Green, J.J. Polymeric nanoparticles as cancer-specific DNA delivery vectors to human hepatocellular carcinoma. J. Control. Release 2017, 263, 18-28. [CrossRef] [PubMed]

137. Botto, C.; Augello, G.; Amore, E.; Emma, M.R.; Azzolina, A.; Cavallaro, G.; Cervello, M.; Bondi, M.L. Cationic Solid Lipid Nanoparticles as Non-Viral Vectors for the Inhibition of Hepatocellular Carcinoma Growth by RNA Interference. J. Biomed. Nanotechnol. 2018, 14, 1009-1016. [CrossRef]

138. Wang, D.; Chang, R.; Wang, G.; Hu, B.; Qiang, Y.; Chen, Z. Polo-like Kinase 1-targeting Chitosan Nanoparticles Suppress the Progression of Hepatocellular Carcinoma. Anticancer Agents Med. Chem. 2017, 17, 948-954. [CrossRef] [PubMed]

139. Mendes, R.; Fernandes, A.R.; Baptista, P.V. Gold Nanoparticle Approach to the Selective Delivery of Gene Silencing in Cancer-The Case for Combined Delivery? Genes (Basel) 2017, 8, 94. [CrossRef] [PubMed]

140. Asokan, A. CRISPR genome editing in stem cells turns to gold. Nat. Mater. 2019, 18, 1038-1039. [CrossRef]

141. Taghizadeh, S.; Alimardani, V.; Roudbali, P.L.; Ghasemi, Y.; Kaviani, E. Gold nanoparticles application in liver cancer. Photodiagnosis Photodyn. Ther. 2019, 25, 389-400. [CrossRef]

142. Yang, N.; Li, S.; Li, G.; Zhang, S.; Tang, X.; Ni, S.; Jian, X.; Xu, C.; Zhu, J.; Lu, M. The role of extracellular vesicles in mediating progression, metastasis and potential treatment of hepatocellular carcinoma. Oncotarget 2017, 8, 3683-3695. [CrossRef]

143. Rinaldi, L.; Folliero, V.; Palomba, L.; Zannella, C.; Isticato, R.; Di Francia, R.; Berretta, M.; de Sio, I.; Adinolfi, L.E.; Morelli, G.; et al. Sonoporation by microbubbles as gene therapy approach against liver cancer. Oncotarget 2018, 9, 32182-32190.

144. Tomizawa, M.; Shinozaki, F.; Motoyoshi, Y.; Sugiyama, T.; Yamamoto, S.; Ishige, N. Suppression of hepatocellular carcinoma cell proliferation by short hairpin RNA of frizzled 2 with Sonazoid-enhanced irradiation. Int. J. Oncol. 2016, 48, 123-129. [CrossRef]

145. Yamashita, Y.; Shimada, M.; Tanaka, S.; Okamamoto, M.; Miyazaki, J.; Sugimachi, K. Electroporation-mediated tumor necrosis factor-related apoptosis-inducing ligand (TRAIL)/Apo2L gene therapy for hepatocellular carcinoma. Hum. Gene Ther. 2002, 13, 275-286. [CrossRef] [PubMed]

146. Harada, N.; Shimada, M.; Okano, S.; Suehiro, T.; Soejima, Y.; Tomita, Y.; Maehara, Y. IL-12 gene therapy is an effective therapeutic strategy for hepatocellular carcinoma in immunosuppressed mice. J. Immunol. 2004, 173, 6635-6644. [CrossRef] [PubMed]

147. Yamashita, Y.; Shimada, M.; Minagawa, R.; Tsujita, E.; Harimoto, N.; Tanaka, S.; Shirabe, K.; Miyazaki, J.; Maehara, Y. Muscle-targeted interleukin-12 gene therapy of orthotopic hepatocellular carcinoma in mice using in vivo electrosonoporation. Mol. Cancer Ther. 2004, 3, 1177-1182. [PubMed]

148. Tan, A.T.; Yang, N.; Lee Krishnamoorthy, T.; Oei, V.; Chua, A.; Zhao, X.; Tan, H.S.; Chia, A.; Le Bert, N.; Low, D.; et al. Use of Expression Profiles of HBV-DNA Integrated Into Genomes of Hepatocellular Carcinoma Cells to Select T Cells for Immunotherapy. Gastroenterology 2019, 156, 1862-1876. [CrossRef] [PubMed]

149. Wang, P.; Qin, W.; Liu, T.; Jiang, D.; Cui, L.; Liu, X.; Fang, Y.; Tang, X.; Jin, H.; Qian, Q. PiggyBac-engineered T cells expressing a glypican-3-specific chimeric antigen receptor show potent activities against hepatocellular carcinoma. Immunobiology 2019. [CrossRef] [PubMed]

150. Leung, K.C.; Chak, C.P.; Lee, S.F.; Lai, J.M.; Zhu, X.M.; Wang, Y.X.; Sham, K.W.; Wong, C.H.; Cheng, C.H. Increased efficacies in magnetofection and gene delivery to hepatocellular carcinoma cells with ternary organic-inorganic hybrid nanocomposites. Chem. Asian J. 2013, 8, 1760-1764. [CrossRef]

151. Liu, F.; Song, Y.; Liu, D. Hydrodynamics-based transfection in animals by systemic administration of plasmid DNA. Gene Ther. 1999, 6, 1258-1266. [CrossRef] 
152. Zhang, G.; Budker, V.; Wolff, J.A. High levels of foreign gene expression in hepatocytes after tail vein injections of naked plasmid DNA. Hum. Gene Ther. 1999, 10, 1735-1737. [CrossRef]

153. Kamimura, K.; Suda, T.; Xu, W.; Zhang, G.; Liu, D. Image-guided, lobe-specific hydrodynamic gene delivery to swine liver. Mol. Ther. 2009, 17, 491-499. [CrossRef]

154. Kamimura, K.; Kanefuji, T.; Yokoo, T.; Abe, H.; Suda, T.; Kobayashi, Y.; Zhang, G.; Aoyagi, Y.; Liu, D. Safety assessment of liver-targeted hydrodynamic gene delivery in dogs. PLoS ONE 2014, 9, e107203. [CrossRef]

155. Abe, H.; Kamimura, K.; Kobayashi, Y.; Ohtsuka, M.; Miura, H.; Ohashi, R.; Yokoo, T.; Kanefuji, T.; Suda, T.; Tsuchida, M.; et al. Effective Prevention of Liver Fibrosis by Liver-targeted Hydrodynamic Gene Delivery of Matrix Metalloproteinase-13 in a Rat Liver Fibrosis Model. Mol. Ther. Nucleic Acids 2016, 5, e276. [CrossRef] [PubMed]

156. Kobayashi, Y.; Kamimura, K.; Abe, H.; Yokoo, T.; Ogawa, K.; Shinagawa-Kobayashi, Y.; Goto, R.; Inoue, R.; Ohtsuka, M.; Miura, H.; et al. Effects of Fibrotic Tissue on Liver-targeted Hydrodynamic Gene Delivery. Mol. Ther. Nucleic Acids 2016, 5, e359. [CrossRef] [PubMed]

157. Cigliano, A.; Wang, C.; Pilo, M.G.; Szydlowska, M.; Brozzetti, S.; Latte, G.; Pes, G.M.; Pascale, R.M.; Seddaiu, M.A.; Vidili, G.; et al. Inhibition of HSF1 suppresses the growth of hepatocarcinoma cell lines in vitro and AKT-driven hepatocarcinogenesis in mice. Oncotarget 2017, 8, 54149-54159. [CrossRef] [PubMed]

158. Li, H.; Wang, Z.; Zhang, J.; Yuan, C.; Zhang, H.; Hou, X.; Zhang, D. Enhanced shRNA delivery by the combination of polyethylenimine, ultrasound, and nanobubbles in liver cancer. Technol. Health Care 2019, 27, 263-272. [CrossRef] [PubMed]

159. Klein, L.; Hinterberger, M.; Wirnsberger, G.; Kyewski, B. Antigen presentation in the thymus for positive selection and central tolerance induction. Nat. Rev. Immunol. 2009, 9, 833-844. [CrossRef] [PubMed]

160. Bos, R.; Marquardt, K.L.; Cheung, J.; Sherman, L.A. Functional differences between low- and high-affinity CD8(+) T cells in the tumor environment. Oncoimmunology 2012, 1, 1239-1247. [CrossRef]

161. Abramson, J.; Giraud, M.; Benoist, C.; Mathis, D. Aire's partners in the molecular control of immunological tolerance. Cell 2010, 140, 123-135. [CrossRef]

162. Rosenberg, S.A.; Yang, J.C.; Sherry, R.M.; Kammula, U.S.; Hughes, M.S.; Phan, G.Q.; Citrin, D.E.; Restifo, N.P.; Robbins, P.F.; Wunderlich, J.R.; et al. Durable complete responses in heavily pretreated patients with metastatic melanoma using T-cell transfer immunotherapy. Clin. Cancer Res. 2011, 17, 4550-4557. [CrossRef]

163. Dudley, M.E.; Yang, J.C.; Sherry, R.; Hughes, M.S.; Royal, R.; Kammula, U.; Robbins, P.F.; Huang, J.; Citrin, D.E.; Leitman, S.F.; et al. Adoptive cell therapy for patients with metastatic melanoma: Evaluation of intensive myeloablative chemoradiation preparative regimens. J. Clin. Oncol. 2008, 26, 5233-5239. [CrossRef]

164. Robbins, P.F.; Morgan, R.A.; Feldman, S.A.; Yang, J.C.; Sherry, R.M.; Dudley, M.E.; Wunderlich, J.R.; Nahvi, A.V.; Helman, L.J.; Mackall, C.L.; et al. Tumor regression in patients with metastatic synovial cell sarcoma and melanoma using genetically engineered lymphocytes reactive with NY-ESO-1. J. Clin. Oncol. 2011, 29, 917-924. [CrossRef]

165. Sterman, D.H.; Recio, A.; Haas, A.R.; Vachani, A.; Katz, S.I.; Gillespie, C.T.; Cheng, G.; Sun, J.; Moon, E.; Pereira, L.; et al. A phase I trial of repeated intrapleural adenoviral-mediated interferon-beta gene transfer for mesothelioma and metastatic pleural effusions. Mol. Ther. 2010, 18, 852-860. [CrossRef] [PubMed]

166. Nemunaitis, J.; Barve, M.; Orr, D.; Kuhn, J.; Magee, M.; Lamont, J.; Bedell, C.; Wallraven, G.; Pappen, B.O.; Roth, A.; et al. Summary of bi-shRNA/GM-CSF augmented autologous tumor cell immunotherapy (FANG) in advanced cancer of the liver. Oncology 2014, 87, 21-29. [CrossRef] [PubMed]

167. Senzer, N.; Barve, M.; Kuhn, J.; Melnyk, A.; Beitsch, P.; Lazar, M.; Lifshitz, S.; Magee, M.; Oh, J.; Mill, S.W.; et al. Phase I trial of "bi-shRNAi(furin)/GMCSF DNA/autologous tumor cell” vaccine (FANG) in advanced cancer. Mol. Ther. 2012, 20, 679-686. [CrossRef] [PubMed]

168. Dhanasekaran, R.; Nault, J.C.; Roberts, L.R.; Zucman-Rossi, J. Genomic Medicine and Implications for Hepatocellular Carcinoma Prevention and Therapy. Gastroenterology 2019, 156, 492-509. [CrossRef] [PubMed]

169. Liu, L.; Cao, Y.; Chen, C.; Zhang, X.; McNabola, A.; Wilkie, D.; Wilhelm, S.; Lynch, M.; Carter, C. Sorafenib blocks the RAF/MEK/ERK pathway, inhibits tumor angiogenesis, and induces tumor cell apoptosis in hepatocellular carcinoma model PLC/PRF/5. Cancer Res. 2006, 66, 11851-11858. [CrossRef] [PubMed]

170. Mazzaferro, V.; El-Rayes, B.F.; Droz Dit Busset, M.; Cotsoglou, C.; Harris, W.P.; Damjanov, N.; Masi, G.; Rimassa, L.; Personeni, N.; Braiteh, F.; et al. Derazantinib (ARQ 087) in advanced or inoperable FGFR2 gene fusion-positive intrahepatic cholangiocarcinoma. Br. J. Cancer 2019, 120, 165-171. [CrossRef] 
171. Doss, W.; Shiha, G.; Hassany, M.; Soliman, R.; Fouad, R.; Khairy, M.; Samir, W.; Hammad, R.; Kersey, K.; Jiang, D.; et al. Sofosbuvir plus ribavirin for treating Egyptian patients with hepatitis C genotype 4. J. Hepatol. 2015, 63, 581-585. [CrossRef]

172. Wang, B.; Hsu, C.J.; Lee, H.L.; Chou, C.H.; Su, C.M.; Yang, S.F.; Tang, C.H. Impact of matrix metalloproteinase-11 gene polymorphisms upon the development and progression of hepatocellular carcinoma. Int. J. Med. Sci. 2018, 15, 653-658. [CrossRef]

173. Petrini, I.; Lencioni, M.; Ricasoli, M.; Iannopollo, M.; Orlandini, C.; Oliveri, F.; Bartolozzi, C.; Ricci, S. Phase II trial of sorafenib in combination with 5-fluorouracil infusion in advanced hepatocellular carcinoma. Cancer Chemother. Pharmacol. 2012, 69, 773-780. [CrossRef]

174. Majzner, R.G.; Mackall, C.L. Clinical lessons learned from the first leg of the CAR T cell journey. Nat. Med. 2019, 25, 1341-1355. [CrossRef]

175. Chen, Y.; E, C.Y.; Gong, Z.W.; Liu, S.; Wang, Z.X.; Yang, Y.S.; Zhang, X.W. Chimeric antigen receptor-engineered T-cell therapy for liver cancer. Hepatobiliary Pancreat. Dis. Int. 2018, 17, 301-309. [CrossRef] [PubMed]

176. Yu, S.; Yi, M.; Qin, S.; Wu, K. Next generation chimeric antigen receptor T cells: Safety strategies to overcome toxicity. Mol. Cancer 2019, 18, 125. [CrossRef] [PubMed]

177. Ruiz de Galarreta, M.; Lujambio, A. Therapeutic editing of hepatocyte genome in vivo. J. Hepatol. 2017, 67, 818-828. [CrossRef] [PubMed]

178. Pankowicz, F.P.; Jarrett, K.E.; Lagor, W.R.; Bissig, K.D. CRISPR/Cas9: At the cutting edge of hepatology. Gut 2017, 66, 1329-1340. [CrossRef]

179. Zhang, H.X.; Zhang, Y.; Yin, H. Genome Editing with mRNA Encoding ZFN, TALEN, and Cas9. Mol. Ther. 2019, 27, 735-746. [CrossRef]

180. Xu, X.; Wan, T.; Xin, H.; Li, D.; Pan, H.; Wu, J.; Ping, Y. Delivery of CRISPR/Cas9 for therapeutic genome editing. J. Gene Med. 2019, 21, e3107. [CrossRef]

(C) 2019 by the authors. Licensee MDPI, Basel, Switzerland. This article is an open access article distributed under the terms and conditions of the Creative Commons Attribution (CC BY) license (http://creativecommons.org/licenses/by/4.0/). 